\title{
PHYSICAL PROPERTIES AND WEATHERING CHARACTERISTICS OF SLATE
}

\author{
By D. W. Kessler and W. H. Sligh
}

\section{ABSTRACT}

Tests on 343 samples of slate from the various districts gave the following average values: Modulus of rupture, $11,700 \mathrm{lbs} . / \mathrm{in}^{2}$; modulus of elasticity in flexure, $13,500,000$ lbs./in. ${ }^{2}$; toughness, 0.192 ; abrasive hardness, $\left(H_{a}\right) 7.6$; absorption, 0.27 per cent by weight; porosity, 0.88 per cent; bulk density, 2.771 ; weight per cubic foot, 172.9 pounds. The strength, elasticity, and toughness values given above were obtained on oven-dried specimens tested in the strongest grain direction. Strength determinations on specimens that had been soaked in water for several days showed considerably lower values. The average ratio of the modulus of rupture of soaked specimens to that of dry specimens was 0.69 .

The examination of a considerable number of slate shingles which had been in service for periods varying from 12 to 130 years indicated that slate deteriorates mainly from a combination of chemical and physical causes. Slates containing both pyrite and calcite in appreciable amounts are subject to decay due to the conversion of a part of the calcite to gypsum. The increase in molecular volume causes scaling of the surface. Slate shingles exposed on the roof decay more rapidly on the downward surface, which is probably due to the leaching and concentration of gypsum. A similar type of decay can be produced by alternately soaking and drying the slate. The slates which are more subject to this type of weathering can be disintegrated by 40 or 50 cycles of this treatment.

Frost may cause deterioration, but the rate of this action is very slow. Aside from chipping off the scales near the edges already loosened in the trimming process, frost plays a very minor part in slate weathering. However, the freezing of water between shingles which are nailed down tightly may cause breakage.

CONTENTS

I. Introduction

II. General description of slate

1. Origin

2. Distribution

3. Classification

4. Cleavage . . .

5. Grain

6. Texture

7. Colors

8. Color permanence.

9. Ribbons

III. Factors affecting service
1. Service conditions

2. Fabrication processes

IV. Composition of slate.

1. Mineral composition

2. Chemical

V. Physical determinations

1. Strength.

2. Elasticity

3. Toughness

4. Abrasive hardness

5. Absorption

6. Porosity

7. Specific gravity

8. Weights per cubic foot

VI. Weathering characteristics

1. Weathering processes

2. Weathering test procedures

VII. Conclusions 


\section{INTRODUCTION}

This paper embraces the results of laboratory studies on the commercial slates of this country and is a continuation of the general investigation relating to various types of stone.

The samples were from nine different States, and consist, mainly, of the materials now found on the market. Fifty samples in the form of large blocks and a large number in the form of shingles were collected especially for this work. Results are also given for numerous samples submitted for various Government buildings. Studies of slate weathering were made of shingles taken from buildings representing exposures of from 12 to 130 years.

While the scope of the paper is limited mainly to physical properties, a brief description of the general characteristics and uses of slate is included as an aid in the interpretation of the results.

The cooperation of the National Slate Association, Bangor Slate Association, Pennsylvania Slate Institute, The Structural Slate Co., and many individual producers was of great assistance and is gratefully acknowledged. The Albion Vein Slate Co. supplied samples from each bed in its quarry at a depth from 190 to 240 feet. The tests on these samples indicate the variations in a section across this quarry and may also be applicable to other quarries on the same "vein."

\section{GENERAL DESCRIPTION OF SLATE}

\section{ORIGIN}

All slates considered herein are assumed to have been formed from very fine argillaceous silts, originally deposited under water in horizontal beds. These beds were compacted by vertical pressures due to subsequent deposits of other sediments. Finally, horizontal pressures distorted the original beds into folds, some of which are now standing in a vertical position, while others are overturned and are resting in a horizontal position. The dynamic action which caused the folding of the beds also caused further consolidation and, by the aid of heat, a process of recrystallization took place which resulted in a marked change in the mineral constituents. The predominating mineral in slate is found to be mica in the form of fine flakes. These flakes are arranged in parallel order, with the flat faces roughly parallel to the axes of the folds. As the original silts were formed from decomposing igneous rocks, the chemical composition of slate bears some relation to that of the parent rock. The geologic age of the slates ranges from Cambrian to Silurian.

\section{DISTRIBUTION}

Although slate deposits are known to exist in 17 States, it is now being produced in only 5 or 6 . The latest statistics indicate that 95 per cent of the roofing slate is supplied by Vermont, Pennsylvania, and Virginia. A large portion of the slate from Maine is used in electrical equipment. The Vermont-New York region supplies red, green, and purple slates for roofing, electrical, and structural purposes, as well as some dark and gray varieties for roofing only. Pennsylvania also produces a large amount of structural and blackboard slate, as well as a considerable quantity for electrical purposes. 


\section{CLASSIFICATION}

Slate is broadly classified under the headings of mica, clay, and igneous slates. A mica slate is one formed from clay sediments, but the process of metamorphism is so complete that the clay content is very small. A clay slate is one in which clay still exists in appreciable quantities, while an igneous slate is one resulting from the metamorphism of a ledge of igneous rock. All materials included in this report are classified as mica slates. The slates of this country have sometimes been subdivided into fading and unfading varieties; but due to the misconceptions arising from such terms and difficulties involved in defining such terms, this phase of the subject will be discussed under a separate heading.

\section{CLEAVAGE}

The distinguishing characteristic of slate is its fissility. Most types of rock may be split more easily in one direction than in another, but in no other type is this property so prominent as in slate. The plane of splitting is commonly called the cleavage plane. Cleavage is evidently due to the parallel arrangement of the mica flakes and the elongation of other mineral constituents in the same general direction. As may be expected, the flattening of the mineral particles occurred on the sides exposed to the greatest pressure and the elongation in the direction of least resistance. The horizontal thrust which caused the folding of the original beds also caused the parallel arrangement of minerals; hence the cleavage is found to make various angles with the original direction of bedding, depending on the part of the fold being considered. At either the apex or trough of a fold the cleavage is commonly perpendicular, while on the sides of the folds it is roughly parallel to the bedding. Not all deposits of slate are as simple as the case just described, and it can not be definitely claimed that horizontal pressures are necessary for the formation of slate. Probably the only necessary conditions are pressures from two opposite directions on a clay stratum with a limited degree of freedom to flow or yield in some other direction. The direction of yielding will determine the cleavage.

\section{GRAIN}

-A slab of slate having its broad faces parallel to the cleavage can be broken transversely in one direction more readily than at right angles to this direction. This direction of easiest breaking is called the "grain," and is caused by the arrangement of the minerals. This feature is assumed to be due to a greater elongation of the mineral in the grain direction than at $90^{\circ}$.

The grain or "sculp" of slate is advantageous in quarrying processes. Mill blocks, or pieces taken from the quarry in convenient size for handling, commonly have the largest faces in the cleavage planes, the next largest in the grain direction, and the least across grain. Likewise in the finished product, when in the form of rectangular slabs, the largest, next largest, and smallest faces will bear the same relation to the cleavage, grain, and cross-grain directions.

There are various ways of determining the grain direction in slate. Slate workers usually resort to the hammer and ascertain the easiest breaking direction in a slab. A means proposed by Jannetaz ${ }^{1}$ 
depends on an assumed difference in thermal conductivity parallel and perpendicular to the grain. This means has not proven very satisfactory as applied to the slates of this country. A method used with considerable success in this study is as follows: A square slab of slate is laid on an asbestos mat with a hole in the center of the latter about 1 inch in diameter. The flame of a Bunsen burner is applied directly to the slate surface through the hole. In a few seconds the slate will usually break in the grain direction.

\section{TEXTURE}

The term "texture" is commonly used by geologists, and mineralogists in describing the state of aggregation of mineral components in rocks. This term in the slate trade has come into a somewhat more restricted use in describing the character of the split surface. A slate which presents a rough cleavage surface when split in the usual way is said to have more "texture" than one that splits evenly. Within recent years architects have often shown a preference for what they call "textural roofs." By using the rougher splitting slates in various sizes and thicknesses they obtain what is designated as "roof texture."

\section{COLORS}

The prevailing color of slates now being produced in Maine, Pennsylvania, and Virginia is dark gray with slight tinges of blue, green, or occasionally brown. Generally the slates from Maine and Virginia present a somewhat darker appearance than the Pennsylvania slates, although the Peach Bottom slates from Maryland and certain beds from Pennsylvania are quite dark. That known as "gray bed" from Pennsylvania, representing a minor part of the total production of that slate, is gray with a tinge of green. The production of red, green, and purple slate is now mainly limited to the Vermont-New York region. A purple slate was once worked in Maryland. Black, red, and green slate deposits occur in Arkansas, and green slates are now being worked to some extent in Georgia and Tennessee.

\section{COLOR PERMANENCE}

The apparent fading which occurs in some of the dark-gray slates seems to be due to an efflorescence of calcium sulphate which partially conceals the true color. During rains, when a slate roof is wet, such fading effects are not apparent, although the same roof may show considerable fading when dry. The source of the calcium sulphate will be discussed under the heading "Weathering processes."

Some of the dark-gray varieties change to a rusty color after a period of exposure. This appears to be due to decomposition of the sulphides of iron in the slate. The first change is probably the formation of sulphate of iron, which is finally oxidized on the exposed surface.

Some of the green varieties of slate also change to buff or rusty brown after a few months of exposure. Such slates have been called "sea green" or "weathering green" slates. This change has been ascribed to the conversion of finely divided particles of iron carbonate to the oxide.

The red, most of the purple, and some of the green varieties undergo no appreciable change of color during long periods of exposure. 
As no satisfactory laboratory test for color permanence has been developed, it has been the practice to rely on past experience with the various deposits. Generally those slates which are low in carbonates undergio the least color changes.

\section{RIBBONS}

Bands of different color, texture, and composition in slate are commonly called "ribbons." The most common ribbons are darker in color than the main part of the slate and vary in width from a fraction of an inch up to several inches. Ribbons follow the original bedding planes of the clay deposits and represent periods of accumulated coarse particles in the sediments. The dark color is due to carbonaceous matter. Such ribbons are usually more absorptive and contain more calcite than the clear part of the slate. Fresh slate containing these ribbons usually shows no appreciable difference in strength whether broken through a ribbon or through the clear part. On account of having coarser particles of quartz the ribbon offers more resistance to cutting or grinding than other parts of the material. The cleavage surface is more uneven and is often deflected somewhat at the ribbon.

Fading effects as mentioned in section 8 above are more common along ribbons, and generally this part is less durable than the clear portion when exposed to the weather.

\section{FACTORS AFFECTING SERVICE}

\section{SERVICE CONDITIONS}

Since the most extensive use of slate is for roofing purposes, the foremost point of concern is durability. A roofing material is obviously exposed to the most severe weather conditions. Roof temperatures may often reach $140^{\circ} \mathrm{F}$, and the exposure offers no protection against the lowest winter temperatures. Moisture, ice, snow, and hail all contribute to the severe conditions. Wind storms deflect the rafters, and where slates are nailed down too tightly may strain them to the breaking point. Besides the normal weather conditions, slate is exposed to flue gases and the leaching from deposits of soot. Evidently the durability of slate in such exposure depends upon the resistance of the mineral component; hence a study of the composition is important. Strength, elasticity, and density are also important characteristics.

Slate also finds extensive use in the form of heavier slabs for steps, floor tile, window sills, toilet stalls, tubs, sinks, etc. In such uses strength and density are important, but probably the most important property is resistance to abrasion. Where exposed to severe wear, as in floors or steps, the presence of hard veins is undesirable because they cause uneven wear.

For blackboards the material has few competitors. Color and texture are the main considerations. In this use of the material, physical tests afford little information of value.

Electrical slate is limited mainly to the products of those deposits which have high insulating values. A slate of high absorption is not apt to prove satisfactory for this purpose unless it is thoroughly dried and treated with some preparation to prevent the entrance of 
moisture. Strength and toughness are important properties, but the final test is that of electrical resistance, and this test it of little value unless applied to the entire panel. The producers of switchboards should have appliances for conducting such tests.

\section{FABRICATION PROCESSES}

Certain processes used in quarrying and working slate into the finished product may have a bearing on its service. The use of explosives in quarrying is quite general. Considerable waste material results, due to shattering, and it seems inevitable that some of the finished product will contain portions of the injured material.

In splitting slabs from quarry blocks the practice is to separate the block into two equal parts by a middle split. The two halves are then divided into halves and so on until the desired thicknesses are obtained. In roofing slate, where no further finishing of the split face is required, there is necessarily a considerable variation in thickness. Slabs which are to be planed to definite thicknesses, as for structural or electrical purposes, must be split to a thickness considerably greater than the finished piece. Slates with curved cleavage are not suitable for such purposes.

The splitting process is varied somewhat according to the nature of the cleavage. Slates having an easy cleavage are split with a long-handled wedge driven into the block on one of the long edges and used as a lever. Slate blocks somewhat more reluctant to split are separated with one wedge, which is driven in the middle of one end and used as a lever. In the most difficult cases the driving of two or more wedges to start the crack is required, and the final separation is made by forcing a long thin blade, shaped like a spatula, down from one end. In all of these methods there is an unavoidable strain produced which is transverse to the slab and greatest in the weakest direction. Thin roofing slates occasionally find their way into the stacks of marketable material which have partially opened transverse cracks running the long way of the shingles. The presence of such cracks can usually be detected by supporting the shingle on the knuckles of one hand and strilking it with a light tool or pencil. If free from cracks it should ring clearly.

Slate shingles are usually trimmed to size, after being split to the desired thickness, by shearing with heavy steel blades. Although this would seem to be a severe treatment for so brittle a material, no very appreciable injury appears to be caused by shearing. However, it probably accounts for the fact that small fragments of slate are often found on the ground near slate roofs. That the slight fracturing near the sheared edge does not affect the durability of the slate is indicated by the fact that decay is more rapid on other parts.

Nail holes are more frequently punched than drilled. Machine punching is usually considered to be more satisfactory than hand punching, although the process is about the same in both. The punch is driven from the side that is to be laid downward. Where the point comes through there is enough chipping around the hole to produce a recess that serves the purpose of countersinking for the nail head. Observations on old shingles seem to indicate that punching is more injurious than the shearing, as decay often begins around the hole before it does on other parts. Some trimming and punching 
must be done by the roofer. As this is done under less favorable conditions than at the plant, it is more apt to prove injurious. Furthermore, slate is less brittle when fresh from the quarry than after it has become seasoned.

\section{COMPOSITION OF SLATE}

\section{MINERAL COMPOSITION}

The prevailing mineral in the commercial slates of this country is sericite mica, which accounts for 30 to 40 per cent of its bulk. Next in order is usually quartz or carbonate of lime, although chlorite, kaolin, or carbon is occasionally found to be next in abundance. Pyrite, magnetite, and rutile are usually present, and occasionally talc, hematite, rhodochrosite, zirocon, tourmaline, pyrrhotite, apatite, limonite, and feldspar. These minerals occur as small scales, lenses, or crystals, the greatest dimension of which is generally a small fraction of a millimeter.

\section{CHEMICAL COMPOSITION}

Chemical analyses made in connection with this study have been confined mainly to weathered slates to determine what changes have occurred. Chemical analyses of various slates have been compiled by Dale in United States Geological Survey Bulletin No. 586. The variations shown for slates from different regions are as follows:

\begin{tabular}{|c|c|c|c|c|}
\hline & Vermont & New York & Pennsylvania & Virginia \\
\hline $\begin{array}{l}\mathrm{SiO}_{2} \\
\mathrm{Al}_{2} \mathrm{O}_{3} \\
\mathrm{Fe}_{2} \mathrm{O}_{3} \\
\mathrm{FeO}_{3} \\
\mathrm{CaO}\end{array}$ & 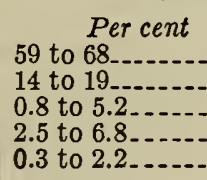 & 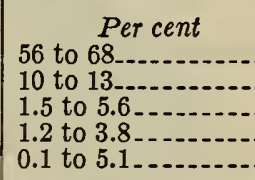 & 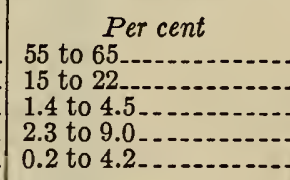 & $\begin{array}{l}\text { Per cent } \\
54 \text { to } 62 . \\
17 \text { to } 25 . \\
7.0 \text { to } 7.8 \text {. } \\
0.4 \text { to } 1.9 .\end{array}$ \\
\hline $\begin{array}{l}\mathrm{MgO} \\
\mathrm{K}_{2} \mathrm{O} \\
\mathrm{Na}_{2} \mathrm{O}-\ldots \\
\mathrm{CO}_{2} \ldots\end{array}$ & $\begin{array}{l}2.2 \text { to } 3.4-- \\
3.5 \text { to } 5.5-- \\
1.1 \text { to } 1.9-- \\
0.1 \text { to } 3.0--\end{array}$ & $\begin{array}{l}3.2 \text { to } 6.4-\ldots \\
2.8 \text { to } 4.4-\ldots \\
0.2 \text { to } 0.8-\cdots \\
0 \text { to } 7.4-\cdots\end{array}$ & $\begin{array}{l}1.5 \text { to } 3.8 \\
1.1 \text { to } 3.7-\ldots . \\
0.5 \text { to } 3.5-\ldots \\
1.6 \text { to } 3.7-\ldots .\end{array}$ & $\begin{array}{l}1.5 \text { to } 3.9 \text {. } \\
0.2 \text { to } 2.0 \text {. }\end{array}$ \\
\hline
\end{tabular}

The chemical composition of various minerals occurring in slate as given in textbooks on mineralogy are as follows:

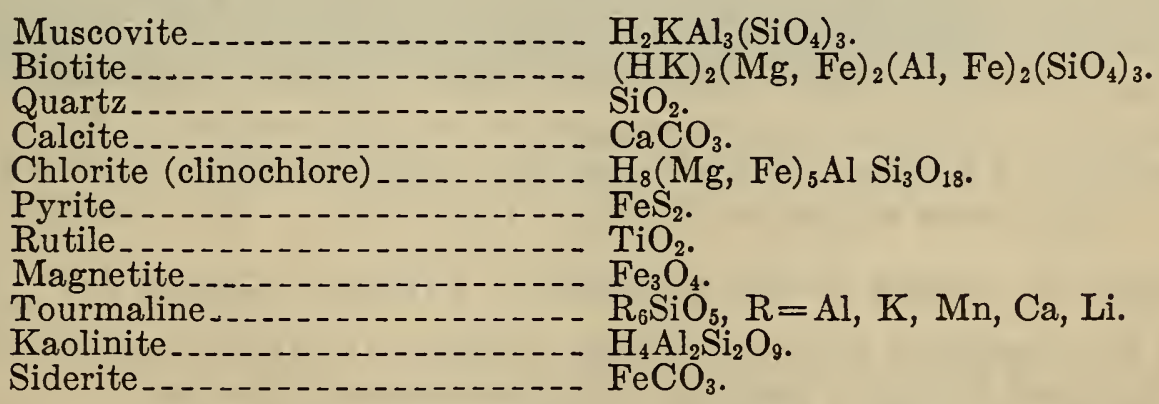

Due to the complex nature of some of these minerals, it is a very difficult, if not impossible, task to determine the true composition from a chemical analysis. Referring to the molecular formulas given above for the predominating minerals in slate, it is seen that silica $\left(\mathrm{SiO}_{2}\right)$ may be ascribed to muscovite, biotite, quartz, chlorite, tour- 
maline, or kaolinite; iron oxides $\left(\mathrm{Fe}_{2} \mathrm{O}_{3}\right.$ and $\left.\mathrm{FeO}\right)$ to biotite, chlorite, magnetite, or siderite; alumina $\left(\mathrm{Al}_{2} \mathrm{O}_{3}\right)$ to muscovite, biotite, chlorite, tourmaline, or kaolinite; lime $(\mathrm{CaO})$ to calcite or tourmaline; magnesia to biotite or chlorite; potassia $\left(\mathrm{K}_{2} \mathrm{O}\right)$ to muscovite, biotite, or tourmaline; soda $\left(\mathrm{Na}_{2} \mathrm{O}\right)$ to muscovite; carbon dioxide to calcite or siderite; sulphur (S) to pyrite; titanium $\left(\mathrm{TiO}_{2}\right)$ to rutile. Water $\left(\mathrm{H}_{2} \mathrm{O}\right)$ determined below $110^{\circ} \mathrm{C}$. is considered to be present in the form of moisture within the pores, while water determined above $110^{\circ}$ C., may form a part of the minerals muscovite, biotite, kaolinite, or one of the chlorite group. Sulphur anhydride $\left(\mathrm{SO}_{3}\right)$ is seldom present in appreciable quantities in fresh slate, but in weathered slates it indicates the presence of gypsum $\left(\mathrm{CaSO}_{4} \mathrm{H}_{2} \mathrm{O}\right)$.

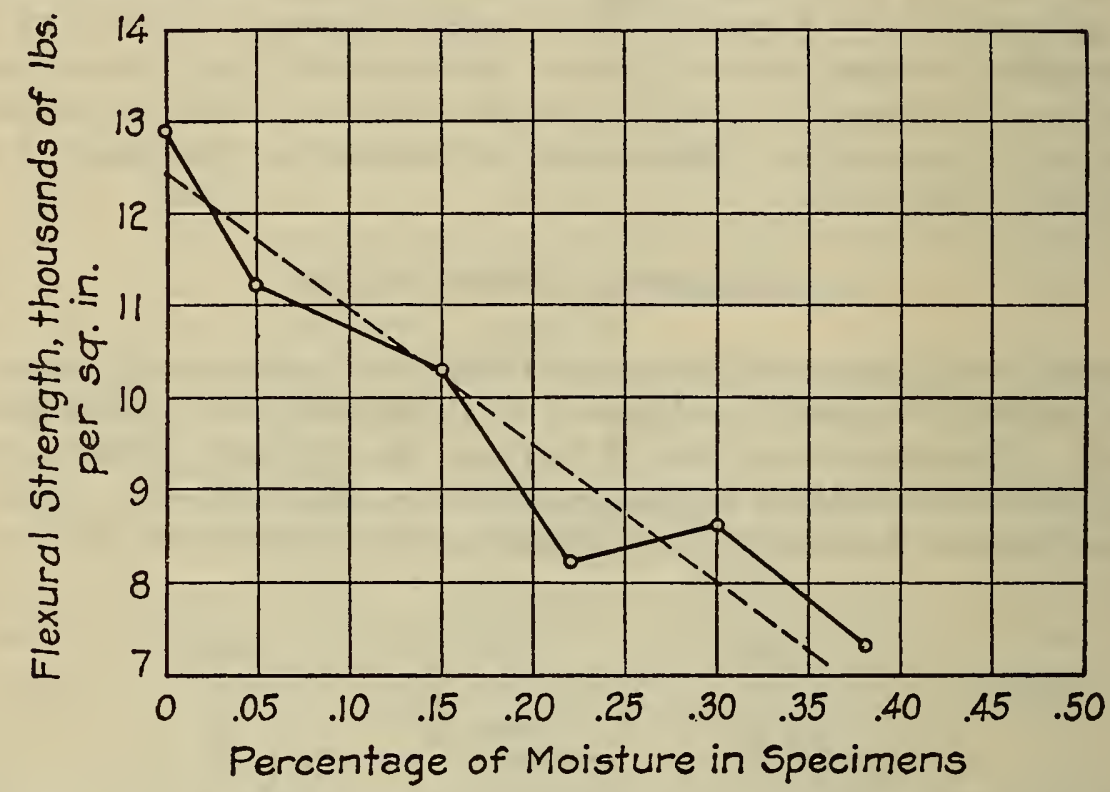

FIGURE 2.-Relation of flexural strength to moisture content of slate Each point on the curve is the average of six strength tests.

\section{PHYSICAL TESTS}

\section{STRENGTH}

The flexural strength of slate is commonly determined instead of compressive, tensile, or shearing strength because of facility in preparing the specimens. In this work a specimen 12 inches long, 4 inches wide, and of thickness varying from one-eighth to one-half inch was generally used. These were tested on the apparatus shown in Figure 1. The pieces were supported on knife-edges of the rocker type spaced 10 inches and loaded at the middle through a third knifeedge. Loads were added in 10-pound increments. The strength was . computed by means of the modulus of rupture formula $R=\frac{W l}{b d^{2}}$ in which $W=$ breaking load, $l=$ length of span, $b=$ width, and $d=$ thickness, the load being in pounds and dimensions in inches.

The strength was usually determined "across the grain"; that is, the long dimension of the specimen was parallel to the grain direction, and hence the fracture was transverse to this direction. Several tests were also made "parallel to the grain" in which the fractural occur- 
B. S. Journal of Research, RP477

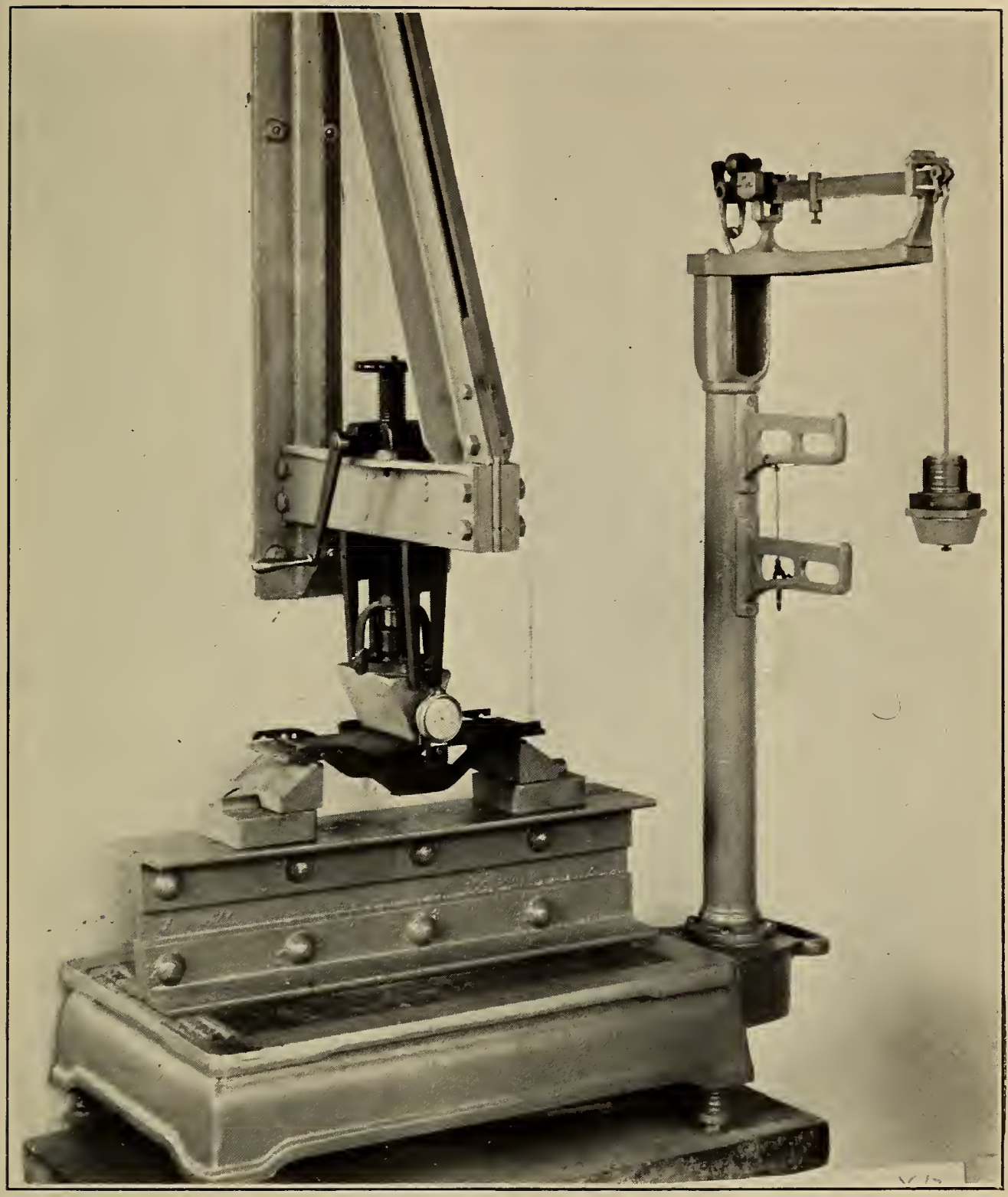

FIGURE 1.-Apparatus used for determining the flexural strength and elasticity of slate 
red in the grain direction. Results of strength tests on slate in the dry condition are given in Table 1.

The effect of absorbed moisture on the strength was studied by tests on several samples after 14 days' soaking. The pronounced reduction in strength is shown in the last column of Table 2. Figure 2 shows strength determinations on several specimens of one slate tested with various amounts of absorbed water. This shows the importance of drying before the strength test if truly comparative results are desired.

TABLE 1.-Modulus of rupture-specimens dry

MAINE SLATES

\begin{tabular}{|c|c|c|c|c|c|c|c|}
\hline \multirow{2}{*}{$\begin{array}{l}\text { Serial } \\
\text { No. }\end{array}$} & \multirow{2}{*}{$\begin{array}{l}\text { Num- } \\
\text { ber of } \\
\text { sam- } \\
\text { ples }\end{array}$} & \multirow{2}{*}{$\begin{array}{l}\text { Num- } \\
\text { ber of } \\
\text { tests }\end{array}$} & \multicolumn{3}{|c|}{$\begin{array}{l}\text { Modulus of rupture, } \\
\text { thousands of Ibs./in.2 }\end{array}$} & \multirow{2}{*}{ Source of sample } & \multirow{2}{*}{ Variety } \\
\hline & & & $\begin{array}{l}\text { Maxi- } \\
\text { mum }\end{array}$ & $\begin{array}{l}\text { Mini- } \\
\text { mum }\end{array}$ & $\begin{array}{l}\text { Aver- } \\
\text { age }\end{array}$ & & \\
\hline $\begin{array}{l}1 .- \\
2 .- \\
3 .-\end{array}$ & $\begin{array}{l}1 \\
2 \\
1 \\
1\end{array}$ & $\begin{array}{l}13 \\
17 \\
23 \\
16\end{array}$ & $\begin{array}{r}10.9 \\
12.1 \\
9.0 \\
15.3\end{array}$ & $\begin{array}{r}10.0 \\
10.2 \\
7.6 \\
9.8\end{array}$ & $\begin{array}{r}10.6 \\
11.0 \\
8.3 \\
13.3\end{array}$ & $\begin{array}{l}\text { Portland Monson Co.... } \\
\text { Monson Maine Co } \\
\text { Rising \& Nelson Slate Co }\end{array}$ & $\begin{array}{l}\text { Blue black. } \\
\text { Do. } \\
\text { Do. } \\
\text { Do. }\end{array}$ \\
\hline
\end{tabular}

VERMONT-NEW YORK SLATES

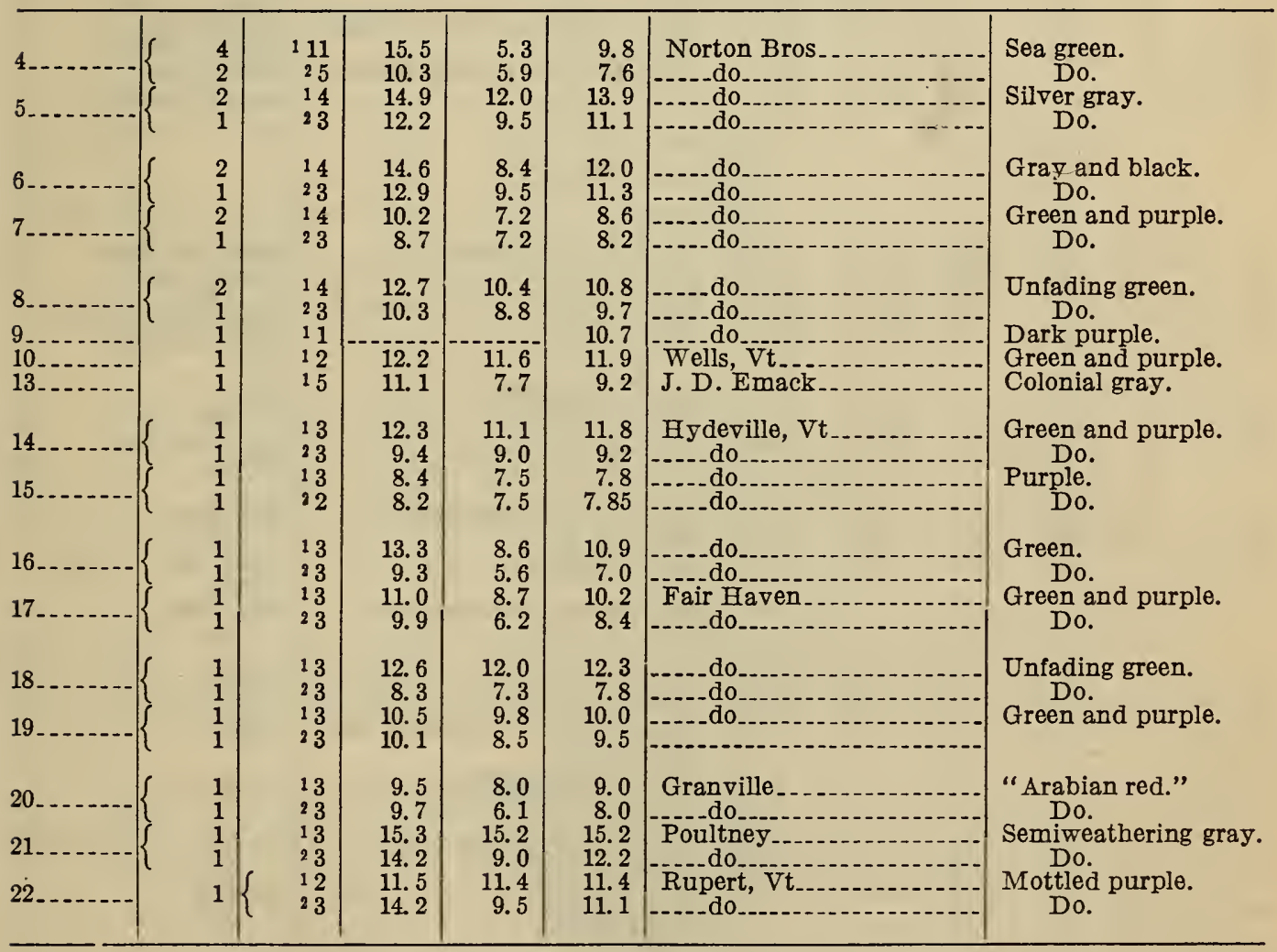

PENNSYLVANIA SLATES

HARD VEIN REGION

\begin{tabular}{|c|c|c|c|c|c|c|c|}
\hline $23 \ldots-1$ & $\begin{array}{r}11 \\
1 \\
5 \\
1\end{array}$ & $\begin{array}{r}144 \\
23 \\
119 \\
16\end{array}$ & $\begin{array}{r}16.5 \\
6.0 \\
16.5 \\
12.7\end{array}$ & $\begin{array}{r}10.0 \\
4.9 \\
9.0 \\
8.4\end{array}$ & $\begin{array}{r}13.8 \\
5.4 \\
13.4 \\
10.8\end{array}$ & $\begin{array}{c}\text { Chapman } \\
\text { Belfast. }\end{array}$ & $\begin{array}{l}\text { Smooth texture. } \\
\text { Do. } \\
\text { Rough texture. } \\
\text { Smooth texture. }\end{array}$ \\
\hline
\end{tabular}

See footnotes at end of table. 


\section{TABLE 1.-Modulus of rupture-specimens dry-Continued}

PENNSYLVANIA SLATES-Continued

BANGOR REGION

\begin{tabular}{|c|c|c|c|c|c|c|c|}
\hline \multirow{2}{*}{$\begin{array}{l}\text { Serial } \\
\text { No. }\end{array}$} & \multirow{2}{*}{$\begin{array}{l}\text { Num- } \\
\text { ber of } \\
\text { sam- } \\
\text { ples }\end{array}$} & \multirow{2}{*}{$\begin{array}{l}\text { Num- } \\
\text { ber of } \\
\text { tests }\end{array}$} & \multicolumn{3}{|c|}{$\begin{array}{l}\text { Modulus of rupture, } \\
\text { thousands of lbs./in.? }\end{array}$} & \multirow{2}{*}{ Source of sample } & \multirow{2}{*}{ Variety } \\
\hline & & & $\begin{array}{l}\text { Maxi- } \\
\text { mum }\end{array}$ & $\begin{array}{l}\text { Mini- } \\
\text { mum }\end{array}$ & $\begin{array}{l}\text { Aver- } \\
\text { age }\end{array}$ & & \\
\hline $\begin{array}{l}26 . \\
27 .\end{array}$ & $\begin{array}{l}3 \\
3 \\
3 \\
3\end{array}$ & $\begin{array}{l}18 \\
25 \\
18 \\
26\end{array}$ & $\begin{array}{r}16.2 \\
10.8 \\
14.8 \\
9.0\end{array}$ & $\begin{array}{l}9.6 \\
6.1 \\
8.2 \\
5.5\end{array}$ & $\begin{array}{r}13.7 \\
7.8 \\
11.5 \\
7.3\end{array}$ & $\begin{array}{l}\text { Structural Slate Co } \\
\text { do }\end{array}$ & $\begin{array}{l}\text { Bangor clear. } \\
\text { Do. } \\
\text { Bangor ribbon. } \\
\text { Do. }\end{array}$ \\
\hline $\begin{array}{l}28 \ldots \\
29-. \\
30 \ldots \\
31 \ldots \\
32 \ldots\end{array}$ & $\begin{array}{l}3 \\
2 \\
2 \\
1 \\
1\end{array}$ & $\begin{array}{l}17 \\
16 \\
14 \\
14 \\
12\end{array}$ & $\begin{array}{l}16.0 \\
12.6 \\
16.0 \\
14.6 \\
14.3\end{array}$ & $\begin{array}{r}7.9 \\
11.5 \\
12.9 \\
12.3 \\
13.9\end{array}$ & $\begin{array}{l}12.2 \\
12.1 \\
14.1 \\
13.4 \\
14.1\end{array}$ & $\begin{array}{l}\text { Vendor Slate Co } \\
\text { Wallace \& Gale } \\
\text { Griffith Consumers Co } \\
\text { Starrett Equipment Co.. }\end{array}$ & $\begin{array}{l}\text { Bangor clear. } \\
\text { Bangor ribbon. } \\
\text { Bangor clear. } \\
\text { Do. } \\
\text { Do. }\end{array}$ \\
\hline $\begin{array}{l}34 . .- \\
35 . .-\end{array}$ & $\begin{array}{l}6 \\
1 \\
1 \\
1\end{array}$ & $\begin{array}{r}118 \\
23 \\
14 \\
14\end{array}$ & $\begin{array}{r}13.9 \\
8.3 \\
11.2 \\
15.2\end{array}$ & $\begin{array}{r}9.9 \\
7.3 \\
10.4 \\
12.0\end{array}$ & $\begin{array}{r}12.2 \\
7.8 \\
10.8 \\
13.8\end{array}$ & N. Bangor Slate Co & $\begin{array}{l}\text { Do. } \\
\text { Do. } \\
\text { Bangor ribbon. } \\
\text { Bangor clear. }\end{array}$ \\
\hline 36 & $\begin{array}{l}2 \\
1\end{array}$ & $\begin{array}{l}18 \\
21\end{array}$ & 13.8 & 11.0 & $\begin{array}{r}12.6 \\
8.1\end{array}$ & $\begin{array}{l}\text { do } \\
\text { do } \\
\text { do... }\end{array}$ & $\begin{array}{c}\text { Bangor ribbon. } \\
\text { Do. }\end{array}$ \\
\hline $\begin{array}{l}37-- \\
38=- \\
39-\end{array}$ & $\begin{array}{l}1 \\
2 \\
1\end{array}$ & $\begin{array}{r}14 \\
110 \\
14\end{array}$ & $\begin{array}{l}12.2 \\
14.7 \\
12.5\end{array}$ & $\begin{array}{l}11.1 \\
10.6 \\
10.4\end{array}$ & $\begin{array}{l}11.7 \\
12.9 \\
11.2\end{array}$ & $\begin{array}{l}\text { Old Bangor Quarries } \\
\text { Bangor Ideal Quarry }\end{array}$ & $\begin{array}{l}\text { Bangor clear. } \\
\text { Bangor ribbon. } \\
\text { Bangor clear. }\end{array}$ \\
\hline $\begin{array}{l}40 \\
41 \\
42 \\
43 \\
44\end{array}$ & $\begin{array}{l}1 \\
1 \\
1 \\
1 \\
1\end{array}$ & $\begin{array}{l}14 \\
14 \\
14 \\
14 \\
14\end{array}$ & $\begin{array}{l}12.1 \\
15.8 \\
16.1 \\
13.1 \\
12.4\end{array}$ & $\begin{array}{r}8.8 \\
13.8 \\
12.6 \\
9.7 \\
10.9\end{array}$ & $\begin{array}{l}10.5 \\
14.6 \\
13.8 \\
11.7 \\
11.5\end{array}$ & $\begin{array}{l}\text { Columbia Bangor Quarry } \\
\text { E. Bangor Consolidated }\end{array}$ & $\begin{array}{l}\text { Bangor ribbon. } \\
\text { Bangor clear. } \\
\text { Bangor ribbon. } \\
\text { Bangor clear. } \\
\text { Bangor ribbon. }\end{array}$ \\
\hline
\end{tabular}

Pen Argri Region

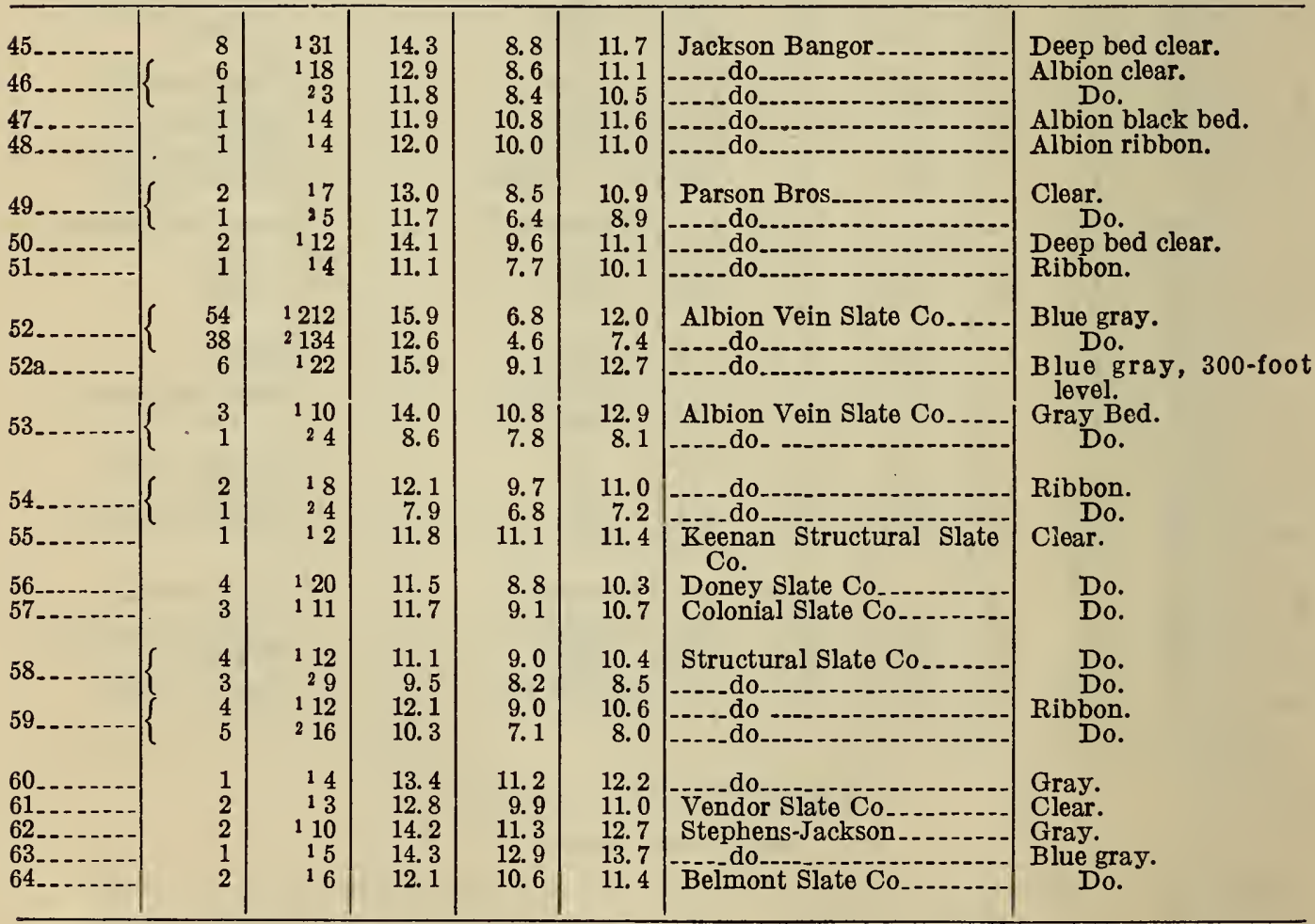

See footnotes at end of table. 
TABLE 1.-Modulus of rupture-specimens dry-Continued

PENNSYLVANIA SLATES-Continued

WIND GaP REgION

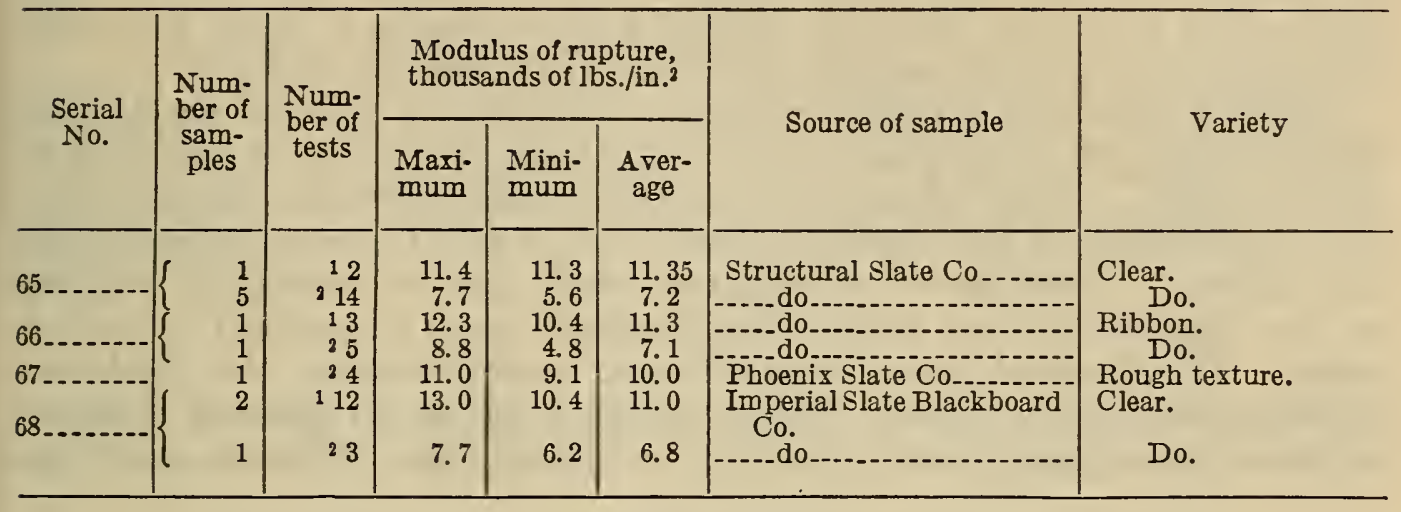

SLATINGTON REgION

\begin{tabular}{|c|c|c|c|c|c|c|c|}
\hline $\begin{array}{l}70 \ldots \\
69 \\
71\end{array}$ & $\begin{array}{l}2 \\
1 \\
3 \\
1\end{array}$ & $\begin{array}{r}14 \\
13 \\
210 \\
12\end{array}$ & $\begin{array}{r}13.3 \\
10.9 \\
9.2 \\
13.0\end{array}$ & $\begin{array}{r}11.6 \\
9.8 \\
4.6 \\
11.3\end{array}$ & $\begin{array}{l}12.4 \\
10.3 \\
6.8 \\
12.15\end{array}$ & $\begin{array}{l}\text { Franklin Big Bed } \\
\text { Structural Slate Co. } \\
\text { Vendor Slate Co }\end{array}$ & $\begin{array}{l}\text { Clear. } \\
\text { Do. } \\
\text { Do. } \\
\text { Rough texture. }\end{array}$ \\
\hline $\begin{array}{l}72 \\
73 \\
74 \\
75 \\
\end{array}$ & $\begin{array}{l}5 \\
2 \\
2 \\
1\end{array}$ & $\begin{array}{r}1 \\
17 \\
15 \\
17 \\
14\end{array}$ & $\begin{array}{r}14.4 \\
12.5 \\
11.1 \\
9.7\end{array}$ & $\begin{array}{l}9.4 \\
9.2 \\
9.7 \\
7.5\end{array}$ & $\begin{array}{r}12.1 \\
11.7 \\
10.4 \\
8.5\end{array}$ & $\begin{array}{l}\text { Washington Big Bed } \\
\text { Slatington Slate Co } \\
\text { Kern Slate Co } \\
\text { Shenton Slate Co }\end{array}$ & $\begin{array}{l}\text { Clear. } \\
\text { Do. } \\
\text { Rough texture. } \\
\text { Clear. }\end{array}$ \\
\hline
\end{tabular}

\section{VIRGINIA}

\begin{tabular}{|c|c|c|c|c|c|c|c|}
\hline 76 & $\begin{array}{l}7 \\
1 \\
7 \\
1 \\
1 \\
1\end{array}$ & $\begin{array}{rl}1 & 22 \\
2 & 3 \\
119 \\
2 & 2 \\
13 \\
22\end{array}$ & $\begin{array}{r}14.2 \\
13.3 \\
12.9 \\
8.2 \\
9.4 \\
2.9\end{array}$ & $\begin{array}{r}8.1 \\
11.3 \\
7.3 \\
6.4 \\
5.8 \\
2.8\end{array}$ & $\begin{array}{l}10.2 \\
12.5 \\
10.6 \\
7.3 \\
7.5 \\
2.85\end{array}$ & $\begin{array}{l}\text { Arvonia } \\
\text { Ore Bank } \\
\text { Esmont }\end{array}$ & $\begin{array}{l}\text { Blue black. } \\
\text { Do. } \\
\text { Do. } \\
\text { Do. } \\
\text { Greenish gray. } \\
\text { Do. }\end{array}$ \\
\hline
\end{tabular}

\section{MARYLAND}

\begin{tabular}{|c|c|c|c|c|c|c|c|}
\hline $\begin{array}{l}79 \ldots-\ldots- \\
80 \\
81 \\
81\end{array}$ & $\begin{array}{l}1 \\
1 \\
1 \\
2\end{array}$ & $\begin{array}{ll}1 & 3 \\
2 & 2 \\
2 & 3 \\
1 & 3\end{array}$ & $\begin{array}{r}9.4 \\
2.9 \\
4.1 \\
15.4\end{array}$ & $\begin{array}{r}5.8 \\
2.8 \\
3.4 \\
15.2\end{array}$ & $\begin{aligned} 7.5 \\
2.85 \\
3.4 \\
15.3\end{aligned}$ & \begin{tabular}{|l} 
Ijamsville. \\
Peach Bottom
\end{tabular} & $\begin{array}{l}\text { Purple. } \\
\text { Do. } \\
\text { Green. } \\
\text { Blue black. }\end{array}$ \\
\hline
\end{tabular}

\section{TENNESSEE}

\begin{tabular}{|c|c|c|c|c|c|c|c|}
\hline $82 \ldots \ldots \ldots$ & $\begin{array}{l}1 \\
1\end{array}$ & $\begin{array}{l}12 \\
23\end{array}$ & $\begin{array}{l}10.6 \\
10.0\end{array}$ & $\begin{array}{l}9.2 \\
8.5\end{array}$ & $\begin{array}{l}9.9 \\
9.0\end{array}$ & Tellico Plains. & Green. \\
\hline \multicolumn{8}{|c|}{ GEORGIA } \\
\hline $83 \ldots$ & $\begin{array}{l}1 \\
1\end{array}$ & $\begin{array}{ll}1 & 3 \\
2 & 3\end{array}$ & $\begin{array}{r}14.5 \\
8.2\end{array}$ & $\begin{array}{l}7.9 \\
5.7\end{array}$ & $\begin{array}{r}11.0 \\
6.7\end{array}$ & Fairmont......... & $\begin{array}{l}\text { Green. } \\
\text { Do. }\end{array}$ \\
\hline \multicolumn{8}{|c|}{ ARRANSAS } \\
\hline 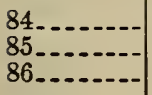 & $\begin{array}{l}1 \\
3 \\
2\end{array}$ & $\begin{array}{r}12 \\
113 \\
15\end{array}$ & $\begin{array}{r}6.5 \\
11.4 \\
7.6\end{array}$ & $\begin{array}{l}3.4 \\
5.2 \\
\text { 3. }\end{array}$ & $\begin{array}{l}4.95 \\
8.1 \\
5.4\end{array}$ & \begin{tabular}{|c|} 
Missouri Mountain \\
do
\end{tabular} & $\begin{array}{l}\text { Black. } \\
\text { Green. } \\
\text { Red. }\end{array}$ \\
\hline
\end{tabular}


The remarkably high flexural strength of slate is probably due to its compactness and the reinforcing effect of the mica particles. The difference in strength between the two grain directions indicates the effect of the elongation of the mica flakes in the grain direction. The lubricating action of water in its effect on strength of stone has been emphasized by Julien ${ }^{2}$ and by Baldwin-Wiseman and Griffith. ${ }^{3}$

Besides affording a ready means of comparing various slates, the flexural strength is of interest in connection with most of the uses of the material. When slate shingles are nailed down too tightly they may be strained to the breaking point due to wind pressures deffecting the rafters. Breakage of shingles on roofs due to workmen walking on the slate or placing ladders on the roof is an important consideration. The flexural strength is a factor in determining the thickness of slabs for various uses. There appears to be no general relation between the strength and durability of slates from different districts.

TABLE 2.-Results of modulus of rupture tests-specimens wet

\begin{tabular}{|c|c|c|c|c|c|c|}
\hline \multirow{2}{*}{ Serial No. ${ }^{1}$} & \multirow{2}{*}{$\begin{array}{c}\text { Number } \\
\text { of } \\
\text { specimens }\end{array}$} & \multirow{2}{*}{$\begin{array}{c}\text { Number } \\
\text { of } \\
\text { tests }\end{array}$} & \multicolumn{3}{|c|}{$\begin{array}{c}\text { Modulus of rupture, thousands } \\
\text { of pounds/in.2 }\end{array}$} & \multirow{2}{*}{$\begin{array}{l}\text { Ratio } \\
\text { wet } \\
\text { strength } \\
\text { to dry } \\
\text { strength }\end{array}$} \\
\hline & & & Maximum & Minimum & Average & \\
\hline 16 & $\begin{array}{l}1 \\
1 \\
1 \\
1 \\
1\end{array}$ & $\begin{array}{ll}2 & 3 \\
3 & 3 \\
3 & 3 \\
3 & 3 \\
3 & 3\end{array}$ & $\begin{array}{r}8.0 \\
7.4 \\
5.2 \\
10.9 \\
5.9\end{array}$ & $\begin{array}{l}7.2 \\
7.0 \\
3.9 \\
6.2 \\
5.7\end{array}$ & $\begin{array}{l}7.7 \\
7.2 \\
4.7 \\
9.1 \\
5.8\end{array}$ & $\begin{array}{l}0.93 \\
.61 \\
.60 \\
.83 \\
.57\end{array}$ \\
\hline $\begin{array}{l}18 \\
19 \\
20 \\
21 \\
22\end{array}$ & $\begin{array}{l}1 \\
1 \\
1 \\
1 \\
1\end{array}$ & 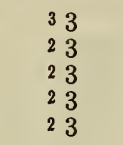 & $\begin{array}{r}6.3 \\
7.2 \\
7.4 \\
11.2 \\
9.6\end{array}$ & $\begin{array}{l}4.4 \\
6.0 \\
6.8 \\
9.7 \\
6.6\end{array}$ & $\begin{array}{r}5.1 \\
6.5 \\
7.1 \\
10.6 \\
8.1\end{array}$ & $\begin{array}{l}.42 \\
.65 \\
.89 \\
.89 \\
.73\end{array}$ \\
\hline $\begin{array}{l}29 \\
52 \\
53 \\
54\end{array}$ & $\begin{array}{r}1 \\
38 \\
1 \\
1 \\
1\end{array}$ & $\begin{aligned} 34 \\
3141 \\
34 \\
34 \\
35\end{aligned}$ & $\begin{array}{r}8.8 \\
12.3 \\
11.0 \\
9.1 \\
9.2\end{array}$ & $\begin{array}{l}7.9 \\
4.9 \\
9.1 \\
7.8 \\
6.9\end{array}$ & $\begin{array}{l}8.4 \\
7.7 \\
9.8 \\
8.3 \\
8.1\end{array}$ & $\begin{array}{l}.69 \\
.66 \\
.74 \\
.74 \\
.66\end{array}$ \\
\hline $\begin{array}{l}63 \\
76,-1 \\
81-\cdots\end{array}$ & $\begin{array}{l}1 \\
1 \\
1 \\
1\end{array}$ & $\begin{array}{lll}\begin{array}{l}3 \\
2\end{array} & 5 \\
2 & 3 \\
3 & 3 \\
3 & 3\end{array}$ & $\begin{array}{r}9.3 \\
10.5 \\
10.1 \\
13.5\end{array}$ & $\begin{array}{l}8.2 \\
9.8 \\
9.4 \\
9.9\end{array}$ & $\begin{array}{r}8.6 \\
10.0 \\
9.8 \\
12.3\end{array}$ & $\begin{array}{r}.63 \\
.80 \\
.64 \\
1.12\end{array}$ \\
\hline
\end{tabular}

1 Identification of serial numbers giren in Table 1.

2 Specimens broken along the grain.

Specimens broken across the grain.

The average modulus of rupture and extreme values for slate from various regions obtained by tests on dry specimens broken across the grain are as follows:

\begin{tabular}{|c|c|c|c|c|}
\hline District & $\begin{array}{l}\text { Number } \\
\text { of tests }\end{array}$ & Average & Maximum & Minimum \\
\hline 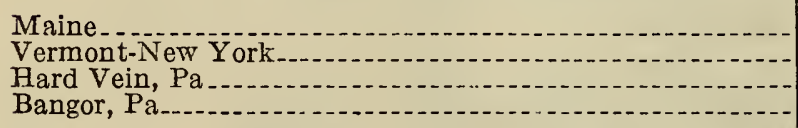 & $\begin{array}{r}21 \\
68 \\
73 \\
156\end{array}$ & $\begin{array}{l}11,700 \\
10,600 \\
13,600 \\
12,500\end{array}$ & $\begin{array}{l}15,300 \\
15,500 \\
16,500 \\
16,300\end{array}$ & $\begin{array}{l}9,800 \\
5,300 \\
8,400 \\
7,900\end{array}$ \\
\hline $\begin{array}{l}\text { Pen Argyl, Pa } \\
\text { Wind Gap, Pa } \\
\text { Slatington, Pa... } \\
\text { Virginia }\end{array}$ & $\begin{array}{r}431 \\
21 \\
35 \\
62\end{array}$ & $\begin{array}{l}11,500 \\
10,900 \\
11,800 \\
10,500\end{array}$ & $\begin{array}{l}15,900 \\
13,000 \\
14,400 \\
14,200\end{array}$ & $\begin{array}{l}6,800 \\
8,500 \\
9,200 \\
6,700\end{array}$ \\
\hline
\end{tabular}

2 Building Stones, J. Franklin Inst., April, May, and June, 1899

3 Minutes of the Proc. Inst. of Civ. Eng., vol. 179, p. 290, 1909. 


\section{ELASTICITY}

The modulus of elasticity in flexure is easily determined in connection with the modulus of rupture test by making deflection measurements at various loads. Determinations in connection with this work were made by suspending the deflectometer shown in Figure 1 from rods laid across the specimen above the supporting knife-edges. The gage used indicated deflections of 0.0001 inch. Usually deflection readings were recorded for each 20 pounds increment of load. The modulus of elasticity, $E$, was computed by means of the formula

$$
E=\frac{W^{\prime} l^{3}}{4 \Delta b d^{3}}
$$

in which $\Delta$ is the deflection corresponding to some chosen load $W^{\prime}$, and $l, b$, and $d$ are the same dimensions used in the modulus of rupture test.

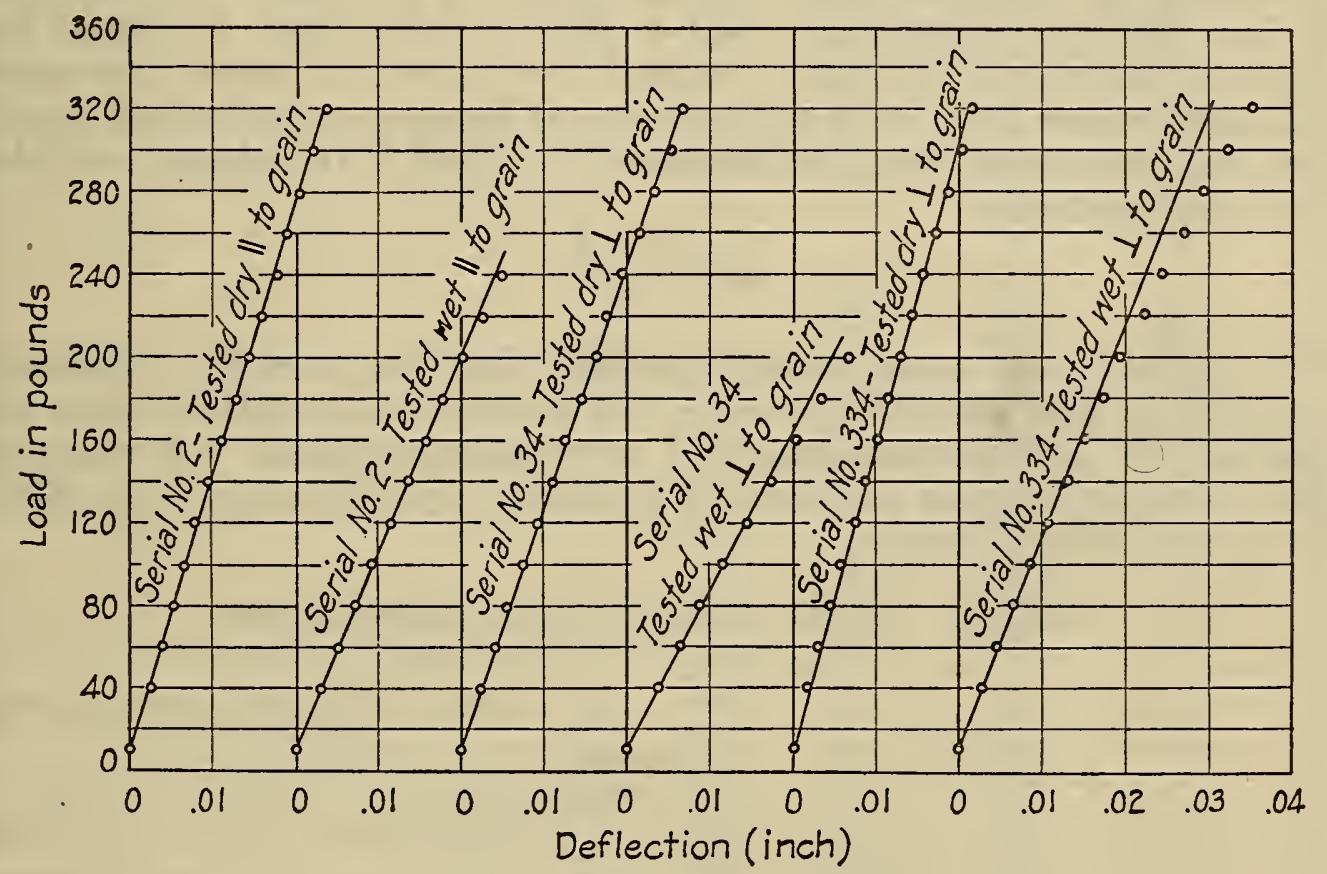

FIGURE 3.-Stress-strain curves for slate in flexure

Figure 3 shows a few stress-strain relations for slate specimens in flexure. In general there is a small deviation from a straight line for loads above half of the breaking load, but no definite yield point is in evidence.

Elasticity determinations have been made in both grain directions on dried specimens and across the grain on several wet specimens. The modulus values are usually. somewhat lower for tests on wet specimens, but show no appreciable difference for tests made in different grain directions $E$ obtained was $13,500,000$, with a maximum of $18,000,000$. There appears to be less variation in the $E$ values for slates from different regions than in other properties. The average $E$ and extreme values $132919-32-8$ 
determined across the grain on dry specimens for the main producing districts are:

\begin{tabular}{|c|c|c|c|c|}
\hline District & $\begin{array}{l}\text { Number } \\
\text { of tests }\end{array}$ & Average & Maximum & Minimum \\
\hline $\begin{array}{l}\text { Maine } \\
\text { Vermont-New York } \\
\text { Hard Vein, Pa... } \\
\text { Bangor, Pa.... }\end{array}$ & $\begin{array}{r}18 \\
63 \\
45 \\
129\end{array}$ & $\begin{array}{l}15,100,000 \\
14,500,000 \\
15,300,000 \\
13,500,000\end{array}$ & $\begin{array}{l}18,000,000 \\
17,600,000 \\
16,700,000 \\
16,300,000\end{array}$ & $\begin{array}{l}13,100,000 \\
12,000,000 \\
13,000,000 \\
10,200,000\end{array}$ \\
\hline $\begin{array}{l}\text { Pen Argyl, } \mathrm{Pa} \\
\text { Slatington, } \mathrm{Pa} \text { a } \\
\text { Wind Gap, } \mathrm{Pa} \\
\text { Virginia............ }\end{array}$ & $\begin{array}{r}259 \\
29 \\
17 \\
56\end{array}$ & $\begin{array}{l}12,900,000 \\
13,400,009 \\
12,400,000 \\
14,700,000\end{array}$ & $\begin{array}{l}15,900,000 \\
15,200,000 \\
13,800,000 \\
16,400,000\end{array}$ & $\begin{array}{r}9,800,000 \\
11,300,000 \\
9,800,000 \\
12,400,000\end{array}$ \\
\hline
\end{tabular}

\section{TOUGHNESS}

Merriman's test ${ }^{4}$ for toughness with slight modifications has been employed in this work. This consists in determing the maximum deflection for a given span and thickness of specimen when loaded in the middle. Merriman used a 22-inch span and recorded the highest observed deflection. In tests made for this report the maximum deflection $\Delta$ for a 16 -inch span and three-sixteenths-inch thickness was computed from the modulus of rupture $R$ and elastic modulus $E$ by the formula

$$
\Delta=\frac{227 R}{E}
$$

This method was found more expedient than to grind the specimens to an exact thickness and observe the maximum deflection, since the grinding to a definite thickness is a very tedious process. A considerable variation in this property is indicated by the toughness values shown in Tables 3 and 4.

TABLE 3.-Results of toughness tests-specimens dry

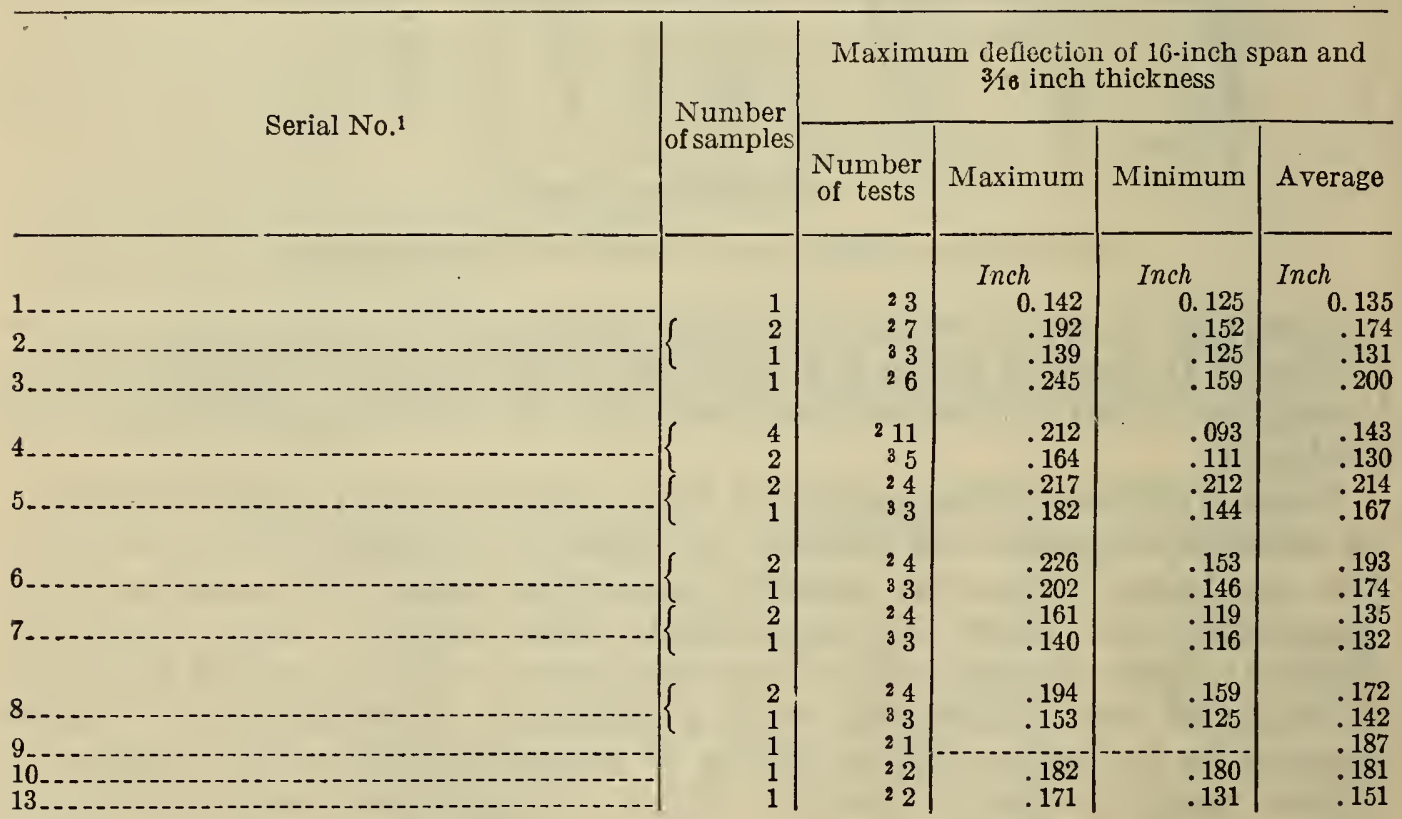

See footnotes at end of table.

4 Strength and Weathering Qualities of Roofing Slates, Trans. Am. Soc. of Civ. Engrs., No. 551, vol. 27 September, 1892. 
TABLE 3.-Results of toughness tests-specrmens dry-Continued

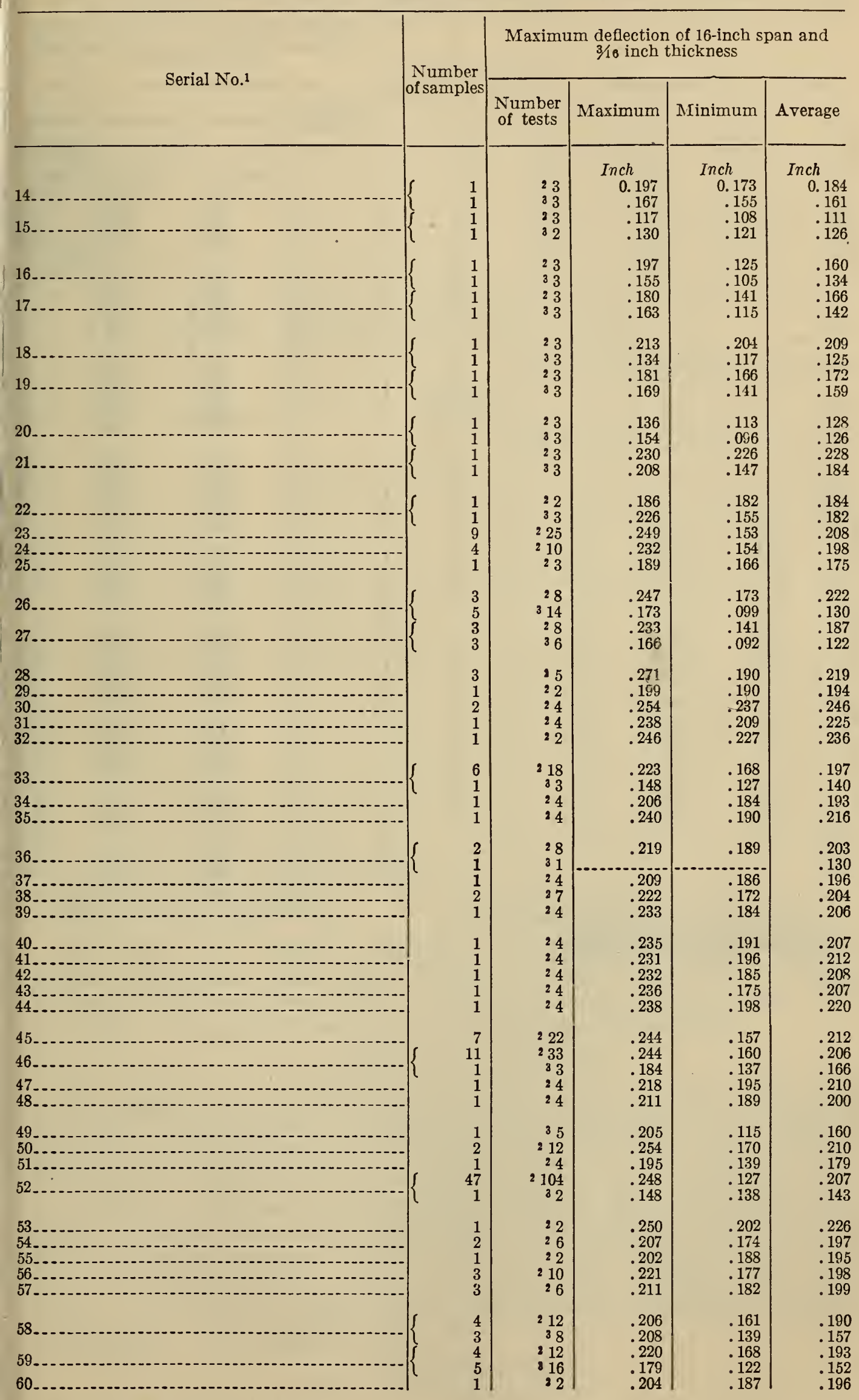

See footnotes at end of table. 
TaBLE 3.-Results of toughness tests-specimens dry-Continued

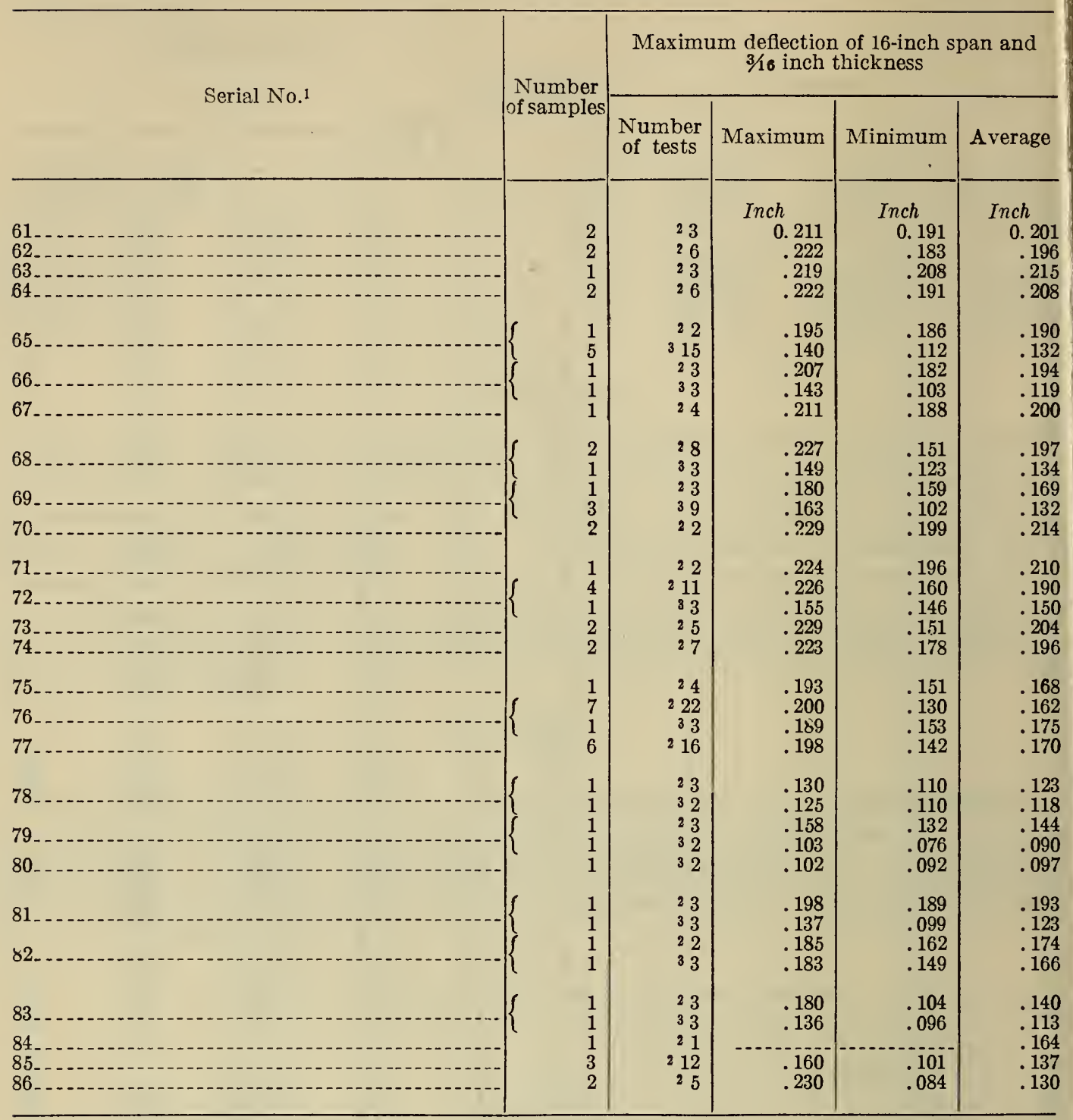

1 Identification of serial numbers given in Table 1.

2 Specimens broken across the grain.

3 Specimens broken along the grain. 
The average and extreme values from tests across the grain on dry specimens for various regions are:

\begin{tabular}{|c|c|c|c|c|}
\hline District & $\begin{array}{l}\text { Number } \\
\text { of tests }\end{array}$ & $\underset{\text { A verage }}{\Delta}$ & $\underset{\text { Maximum }}{\Delta}$ & $\underset{\text { Minimum }}{\Delta}$ \\
\hline 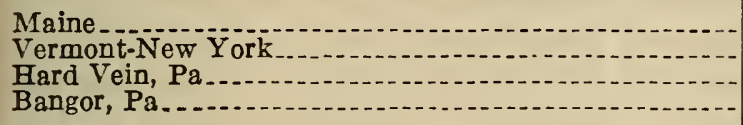 & $\begin{array}{r}18 \\
63 \\
45 \\
125\end{array}$ & $\begin{array}{r}0.178 \\
.163 \\
.204 \\
.205\end{array}$ & $\begin{array}{l}0.245 \\
.230 \\
.249 \\
.271\end{array}$ & $\begin{array}{l}0.125 \\
.093 \\
.153 \\
.141\end{array}$ \\
\hline 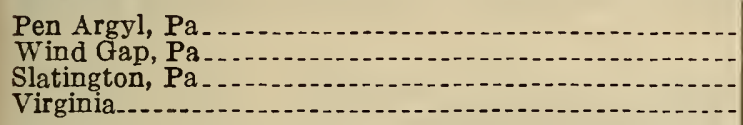 & $\begin{array}{r}263 \\
17 \\
29 \\
56\end{array}$ & $\begin{array}{l}.205 \\
.196 \\
.197 \\
.164\end{array}$ & $\begin{array}{l}.250 \\
.227 \\
.229 \\
.200\end{array}$ & $\begin{array}{l}.127 \\
.151 \\
.151 \\
.106\end{array}$ \\
\hline
\end{tabular}

TABLE 4.-Results of toughness tests-specimens wet

\begin{tabular}{|c|c|c|c|c|c|}
\hline \multirow{2}{*}{ Serial No. ${ }^{1}$} & \multirow{2}{*}{$\begin{array}{l}\text { Number } \\
\text { of samples }\end{array}$} & \multicolumn{4}{|c|}{$\begin{array}{l}\text { Maximum deflection of } 16 \text {-inch span and } \\
3 / 10 \text { inch thickness }\end{array}$} \\
\hline & & $\begin{array}{l}\text { Number } \\
\text { of tests }\end{array}$ & Maximum & Minimum & Average \\
\hline 2. & $\begin{array}{l}1 \\
1 \\
1 \\
1 \\
1\end{array}$ & $\begin{array}{l}22 \\
323 \\
33 \\
33 \\
33 \\
3\end{array}$ & $\begin{array}{c}\text { Inch } \\
0.126 \\
.136 \\
.089 \\
.180 \\
.134\end{array}$ & $\begin{array}{l}\text { Inch } \\
0.120 \\
.131 \\
.065 \\
.131 \\
.126\end{array}$ & $\begin{array}{c}\text { Inch } \\
0.124 \\
.134 \\
.080 \\
.161 \\
.130\end{array}$ \\
\hline $21-22$ & $\begin{array}{l}1 \\
1 \\
1 \\
1 \\
1\end{array}$ & $\begin{array}{l}83 \\
23 \\
23 \\
23 \\
23\end{array}$ & $\begin{array}{r}.127 \\
.1150 \\
.132 \\
.133 \\
.172\end{array}$ & $\begin{array}{l}.090 \\
.118 \\
.121 \\
.165 \\
.113\end{array}$ & $\begin{array}{l}.105 \\
.131 \\
.125 \\
.176 \\
.143\end{array}$ \\
\hline 62 & $\begin{array}{r}33 \\
1 \\
1 \\
2\end{array}$ & $\begin{array}{r}368 \\
32 \\
32 \\
34\end{array}$ & $\begin{array}{l}.202 \\
.192 \\
.185 \\
.176\end{array}$ & $\begin{array}{r}.114 \\
.169 \\
.172 \\
.132\end{array}$ & $\begin{array}{r}.168 \\
.180 \\
.178 \\
.152\end{array}$ \\
\hline 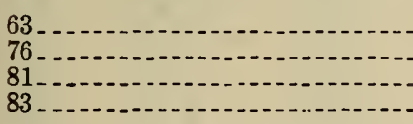 & $\begin{array}{l}1 \\
1 \\
1 \\
1\end{array}$ & $\begin{array}{l}82 \\
83 \\
33 \\
33 \\
33\end{array}$ & $\begin{array}{l}.184 \\
.151 \\
.180 \\
.176\end{array}$ & $\begin{array}{l}.170 \\
.140 \\
.167 \\
.127\end{array}$ & $\begin{array}{l}.177 \\
.146 \\
.172 \\
.160\end{array}$ \\
\hline
\end{tabular}

1 Identification of serial numbers given in Table 1.

2 Specimens broken along the grain.

3 Specimens broken across the grain.

This test is of value in showing the flexibility of the material. Other properties being equal, a slate of high toughness is less apt to break under a given strain than one of lower toughness. This property is sometimes used as a specification requirement.

\section{ABRASIVE HARDNESS}

The apparatus used in determining the abrasive hardness values given in Table 5 is described in detail in the Proceedings of the American Society for Testing Materials, volume 28, part 2, 1928, pages 855-867. The result is expressed as a reciprocal of the volume abraded under controlled conditions in a given period of time. The specimens, which were 2 inches square and 1 inch thick, were weighed and subjected to the abrading process, after which they were weighed again. By means of the apparent specific gravity of the material the weight loss is converted to volume, since this gives a more definite basis of comparison. The reduction formula is

$$
H_{a}=\frac{10\left(2,000+W_{s}\right) G}{2,000 W_{a}}
$$


in which $W_{s}$ is the weight of the specimen, $G$ the apparent specific gravity, and $W_{a}$ the loss of weight by abrasion. The constant load on the specimen during the grinding is $2,000 \mathrm{G}$ which is augmented by the variable weight of the specimen. In applying the correction for the weight $W_{s}$ the average of the original and final weights is used. The reciprocal relation is used in order to give values in conformity with the usual conceptions of hardness; that is, low values for soft materials and higher values to harder materials. The factor 10 in the numerator is used arbitrarily to avoid values less than unity for soft materials.

TABLE 5.-Results of abrasive hardness tests

\begin{tabular}{|c|c|c|c|c|c|}
\hline \multirow{2}{*}{ Serial No. ${ }^{1}$} & \multirow{2}{*}{$\begin{array}{c}\text { Number } \\
\text { of } \\
\text { samples }\end{array}$} & \multicolumn{4}{|c|}{ Hardness values $\left(H_{a}\right)$} \\
\hline & & $\begin{array}{l}\text { Number } \\
\text { of tests }\end{array}$ & Maximum & Minimum & Average \\
\hline $\begin{array}{l}{ }^{1} \\
{ }^{2}\end{array}$ & $\begin{array}{l}1 \\
1 \\
1 \\
1 \\
1\end{array}$ & $\begin{array}{l}3 \\
5 \\
5 \\
5 \\
5\end{array}$ & $\begin{array}{l}9.4 \\
9.8 \\
8.0 \\
7.8 \\
7.2\end{array}$ & $\begin{array}{l}8.8 \\
9.3 \\
7.6 \\
7.2 \\
7.0\end{array}$ & $\begin{array}{l}9.1 \\
9.6 \\
7.7 \\
7.5 \\
7.1\end{array}$ \\
\hline 8 & $\begin{array}{l}1 \\
1 \\
1 \\
1 \\
1\end{array}$ & $\begin{array}{l}6 \\
6 \\
5 \\
5 \\
6\end{array}$ & $\begin{array}{r}15.2 \\
7.6 \\
8.5 \\
9.0 \\
8.1\end{array}$ & $\begin{array}{l}7.4 \\
7.2 \\
7.6 \\
6.9 \\
7.0\end{array}$ & $\begin{array}{r}11.7 \\
7.5 \\
8.0 \\
8.3 \\
7.6\end{array}$ \\
\hline 18 & $\begin{array}{l}1 \\
1 \\
1 \\
1 \\
1\end{array}$ & $\begin{array}{l}6 \\
6 \\
4 \\
3 \\
5\end{array}$ & $\begin{array}{r}9.2 \\
8.7 \\
8.9 \\
12.2 \\
7.9\end{array}$ & $\begin{array}{r}8.8 \\
8.1 \\
7.4 \\
11.0 \\
7.5\end{array}$ & $\begin{array}{r}9.0 \\
8.5 \\
7.9 \\
11.8 \\
7.7\end{array}$ \\
\hline 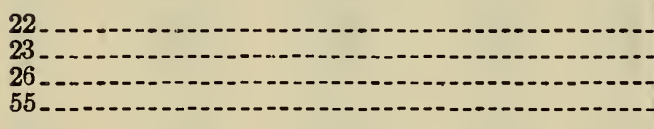 & $\begin{array}{l}1 \\
1 \\
3 \\
1\end{array}$ & $\begin{array}{r}5 \\
26 \\
9 \\
5\end{array}$ & $\begin{array}{l}7.3 \\
9.3 \\
7.2 \\
7.2\end{array}$ & $\begin{array}{l}6.7 \\
8.1 \\
6.8 \\
5.8\end{array}$ & $\begin{array}{l}6.9 \\
8.7 \\
6.9 \\
6.5\end{array}$ \\
\hline 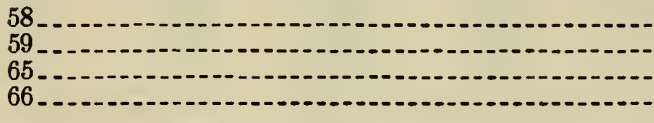 & $\begin{array}{l}2 \\
2 \\
4 \\
2\end{array}$ & $\begin{array}{r}12 \\
15 \\
12 \\
26\end{array}$ & $\begin{array}{l}7.2 \\
7.2 \\
6.4 \\
7.2\end{array}$ & $\begin{array}{l}6.3 \\
6.2 \\
5.6 \\
6.5\end{array}$ & $\begin{array}{l}6.8 \\
6.6 \\
6.0 \\
6.9\end{array}$ \\
\hline $\begin{array}{l}69 \\
86 \\
83\end{array}$ & $\begin{array}{l}2 \\
1 \\
1 \\
1\end{array}$ & $\begin{array}{l}6 \\
5 \\
3 \\
5\end{array}$ & $\begin{array}{r}5.8 \\
12.2 \\
5.7 \\
8.9\end{array}$ & $\begin{array}{l}5.5 \\
9.9 \\
5.5 \\
7.9\end{array}$ & $\begin{array}{r}5.6 \\
10.9 \\
5.6 \\
8.4\end{array}$ \\
\hline
\end{tabular}

1 Identification of serial numbers given in Table 1.

2 All specimens contained ribbons.

3 Nine specimens contained ribbons.

A comparison of the $H_{a}$ values in Table 5 with the service records of various slates shows considerable evidence that hardness is directly proportional to durability. However, the very low $H_{a}$ value for one slate, which has so thoroughly established its good weathering quality by long service, can be cited to prove that no general relation between hardness and durability exists.

The range in hardness values for slates from different districts was not found to be as great as for other materials of a given type, as marble, limestone, etc. The average and extreme $H_{G}$ values for various regions were as follows: 


\begin{tabular}{|c|c|c|c|c|}
\hline District & $\underset{\text { tests }}{\text { Number of }}$ & $H_{a}$ average & $\underset{\text { mum }}{H_{a} \operatorname{maxi}-}$ & $\underset{\text { mum }}{H_{a} \operatorname{mini}}$ \\
\hline $\begin{array}{l}\text { Maine } \\
\text { Vermont-New York } \\
\text { Bard Vein, Pa } \\
\text { Bangor, Pa }\end{array}$ & $\begin{array}{r}8 \\
72 \\
9 \\
6\end{array}$ & $\begin{array}{l}9.4 \\
8.3 \\
8.2 \\
6.8\end{array}$ & $\begin{array}{r}9.8 \\
15.2 \\
9.3 \\
7.0\end{array}$ & $\begin{array}{l}8.8 \\
6.7 \\
7.0 \\
6.8\end{array}$ \\
\hline $\begin{array}{l}\text { Pen Argyl, Pa } \\
\text { Wind Gap, Pa- } \\
\text { Slatington, Pa } \\
\text { Virginia }\end{array}$ & $\begin{array}{r}32 \\
18 \\
6 \\
5\end{array}$ & $\begin{array}{r}6.7 \\
6.3 \\
5.6 \\
10.9\end{array}$ & $\begin{array}{r}7.2 \\
7.2 \\
5.8 \\
12.2\end{array}$ & $\begin{array}{l}5.8 \\
5.6 \\
5.5 \\
9.9\end{array}$ \\
\hline
\end{tabular}

The dark "ribbons" in the slates from Pennsylvania are usually more resistant to abrasion than the parts of the slate free from ribbons. According to Dale ${ }^{5}$ and Behre, ${ }^{6}$ this is due to the presence of coarser quartz particles in the ribbons.

The abrasive hardness of the material is of interest in cases where it is to be used in floors, steps, sills, sinks, table tops, etc., but probably has no significance in connection with roofing slate.

\section{ABSORPTION}

The absorption test is frequently used in roofing-slate specifications, and there appears to be a relation between absorption values and weathering qualities. The values given in Table 6 were determined on slabs from 4 to 6 inches square and from three-sixteenths to onefourth inch thick. These were dried at $100^{\circ} \mathrm{C}$. for 24 hours for the dry weight, and then completely immersed in water at room temperatures for 48 hours. Absorption results are given in percentage by weight, which were determined by dividing the weight of water absorbed by the weight of the dry specimen. The weight ratio is commonly used in specification tests, but the volume ratio is a more definite means of comparison. The errors arising from the use of the weight ratios are not as great for slate as for most other materials, since the variation in "bulk density" from one slate to another is comparatively small.

TABLE 6.-Results of absorption tests

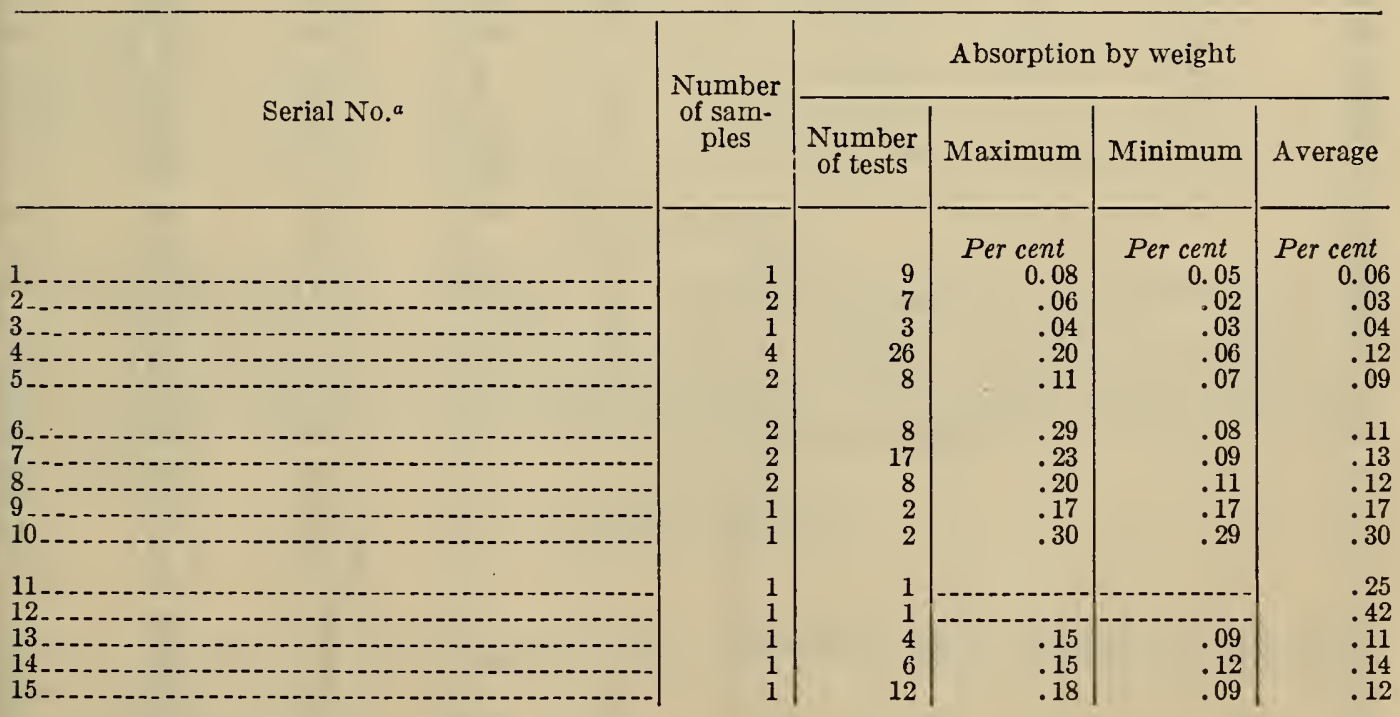

a Identification of serial numbers given in Table 1.

$\checkmark$ U. S. Geological Survey Bulletin No. 586.

Slate in Northampton County, Pa., Bul. M9, Topographic and Geologic Survey of Pennsylvania, 1927. 
TABLE 6.-Results of absorption tests-Continued

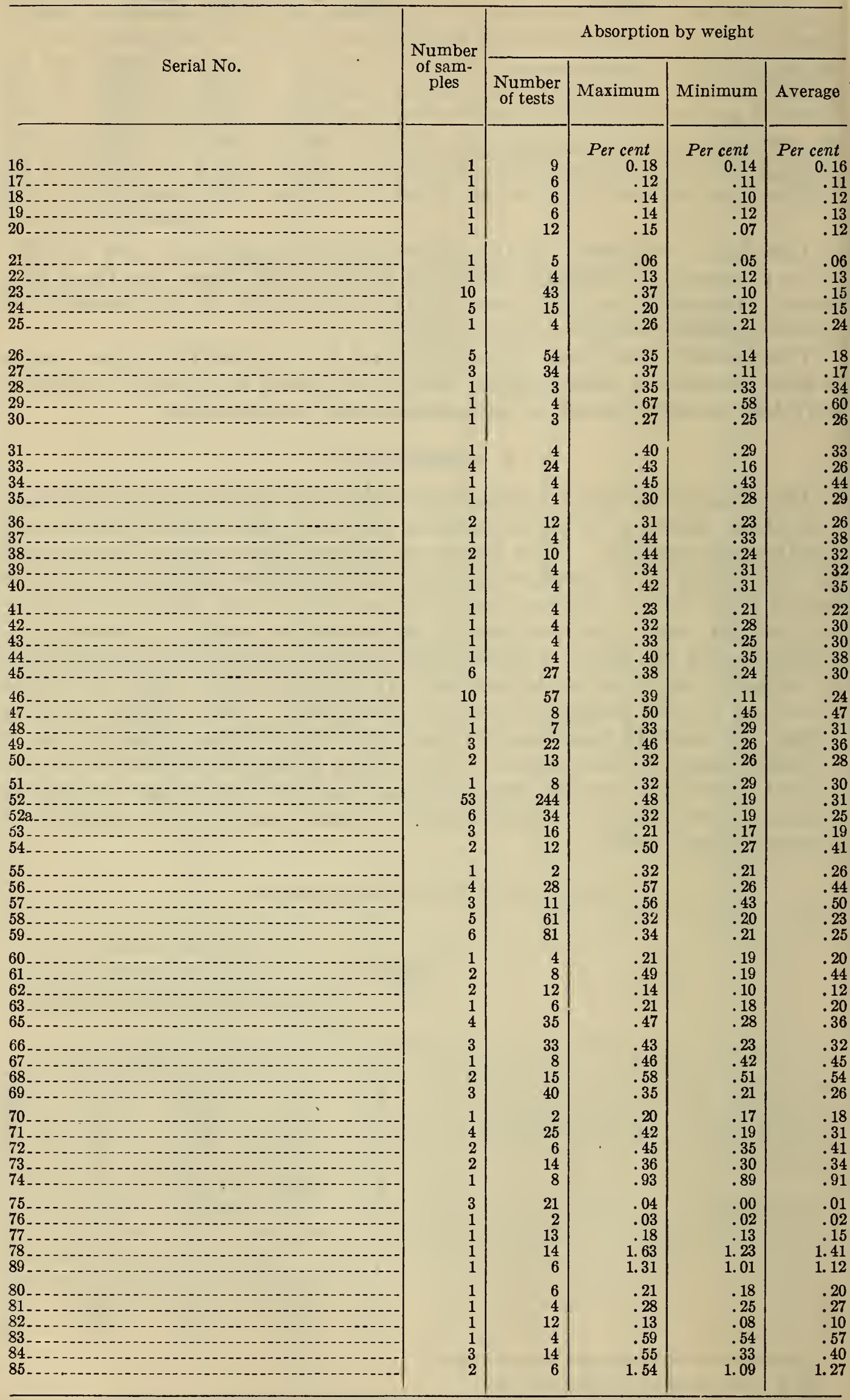


TABLE 7.-True specific gravity, apparent specific gravity, porosity, and weight per cubic foot

\begin{tabular}{|c|c|c|c|c|c|c|c|c|c|c|c|c|}
\hline \multirow[b]{2}{*}{ Serial No. ${ }^{1}$} & \multicolumn{5}{|c|}{ True specific gravity } & \multicolumn{5}{|c|}{ Apparent specific gravity } & \multirow{2}{*}{$\begin{array}{c}\text { Po- } \\
\text { rosity } \\
\text { per } \\
\text { cent } \\
\text { by } \\
\text { vol- } \\
\text { ume }\end{array}$} & \multirow{2}{*}{$\begin{array}{l}\text { Weight } \\
\text { per } \\
\text { cubic } \\
\text { foot } \\
\text { (dry) }\end{array}$} \\
\hline & $\begin{array}{l}\text { Num- } \\
\text { ber of } \\
\text { sam- } \\
\text { ples }\end{array}$ & $\begin{array}{l}\text { Num- } \\
\text { ber of } \\
\text { tests }\end{array}$ & $\begin{array}{l}\text { Maxi- } \\
\text { mum }\end{array}$ & $\begin{array}{l}\text { Mini- } \\
\text { mum }\end{array}$ & $\begin{array}{l}\text { Aver- } \\
\text { age }\end{array}$ & $\begin{array}{l}\text { Num- } \\
\text { ber of } \\
\text { sam- } \\
\text { ples }\end{array}$ & $\begin{array}{l}\text { Num- } \\
\text { ber of } \\
\text { tests }\end{array}$ & $\begin{array}{l}\text { Maxi- } \\
\text { mum }\end{array}$ & $\begin{array}{l}\text { Mini- } \\
\text { mum }\end{array}$ & $\begin{array}{c}\text { Aver- } \\
\text { age }\end{array}$ & & \\
\hline & $\begin{array}{l}1 \\
1\end{array}$ & $\begin{array}{l}5 \\
3\end{array}$ & $\begin{array}{l}2.833 \\
2.831\end{array}$ & $\begin{array}{l}2.816 \\
2.826\end{array}$ & $\begin{array}{l}2.823 \\
2.829\end{array}$ & 1 & $\begin{array}{l}9 \\
6 \\
6\end{array}$ & & $\begin{array}{l}2.806 \\
2.820\end{array}$ & & $\begin{array}{r}0.57 \\
.28\end{array}$ & $\begin{array}{l}\text { 175. } 2 \\
176.0\end{array}$ \\
\hline & $\begin{array}{l}3 \\
1\end{array}$ & $\begin{array}{r}11 \\
3\end{array}$ & $\begin{array}{l}\text { 2. } 803 \\
\text { 2. } 782\end{array}$ & $\begin{array}{l}2.768 \\
2.778\end{array}$ & $\begin{array}{l}2.787 \\
2.780\end{array}$ & $\begin{array}{l}3 \\
1\end{array}$ & $\begin{array}{r}18 \\
6\end{array}$ & $\begin{array}{l}2.776 \\
2.773\end{array}$ & $\begin{array}{l}2.758 \\
2.770\end{array}$ & $\begin{array}{l}2.767 \\
2.772\end{array}$ & $\begin{array}{l}.74 \\
.29\end{array}$ & $\begin{array}{l}172.6 \\
173.0\end{array}$ \\
\hline- & $\begin{array}{l}1 \\
1 \\
1 \\
1 \\
1\end{array}$ & $\begin{array}{l}3 \\
3 \\
3 \\
5 \\
3\end{array}$ & $\begin{array}{l}2.776 \\
2.812 \\
2.788 \\
2.814 \\
2.828\end{array}$ & $\begin{array}{l}2.767 \\
2.806 \\
2.781 \\
2.810 \\
2.825\end{array}$ & $\begin{array}{l}2.772 \\
2.809 \\
2.786 \\
2.812 \\
2.827\end{array}$ & $\begin{array}{l}1 \\
1 \\
1 \\
1 \\
1\end{array}$ & $\begin{array}{l}6 \\
6 \\
6 \\
6 \\
6\end{array}$ & & $\begin{array}{l}2.763 \\
2.790 \\
2.768 \\
2.791 \\
2.810\end{array}$ & & $\begin{array}{l}.29 \\
.46 \\
.61 \\
.50 \\
.57\end{array}$ & $\begin{array}{l}172.4 \\
174.5 \\
172.8 \\
174.6 \\
175.4\end{array}$ \\
\hline- & $\begin{array}{l}1 \\
1 \\
1 \\
1 \\
1\end{array}$ & $\begin{array}{l}3 \\
3 \\
3 \\
3 \\
3\end{array}$ & $\begin{array}{l}2.808 \\
2.821 \\
2.808 \\
2.809 \\
2.805\end{array}$ & $\begin{array}{l}2.805 \\
2.819 \\
2.802 \\
2.808 \\
2.802\end{array}$ & $\begin{array}{l}2.806 \\
2.820 \\
2.804 \\
2.809 \\
2.803\end{array}$ & $\begin{array}{l}1 \\
1 \\
1 \\
1 \\
1\end{array}$ & $\begin{array}{l}6 \\
6 \\
6 \\
6 \\
6\end{array}$ & & & & $\begin{array}{l}.78 \\
.35 \\
.57 \\
.68 \\
.29\end{array}$ & $\begin{array}{l}173.7 \\
175.4 \\
174.0 \\
174.1 \\
174.4\end{array}$ \\
\hline 2 & $\begin{array}{l}1 \\
1\end{array}$ & $\begin{array}{l}3 \\
3\end{array}$ & $\begin{array}{r}2.775 \\
2.810 \\
\end{array}$ & $\begin{array}{r}2.772 \\
2.805\end{array}$ & 2. & $\begin{array}{l}1 \\
1 \\
2\end{array}$ & $\begin{array}{l}5 \\
4 \\
4\end{array}$ & & & & $\begin{array}{l}.36 \\
.89\end{array}$ & $\begin{array}{l}172.5 \\
173.7 \\
172.4\end{array}$ \\
\hline & 4 & 16 & 2.795 & 2. 774 & 2.785 & 5 & 47 & 2.775 & 2.7 & 2.763 & .79 & 172.4 \\
\hline & 2 & 6 & 2.775 & 2. 769 & 2.772 & $\begin{array}{l}2 \\
1 \\
1 \\
2 \\
1\end{array}$ & $\begin{array}{r}23 \\
2 \\
2 \\
6 \\
4\end{array}$ & & & & .51 & $\begin{array}{l}172.1 \\
173.0 \\
173.4 \\
173.0 \\
172.1\end{array}$ \\
\hline & 1 & 4 & 2.810 & $\begin{array}{c}2.792 \\
2.760\end{array}$ & $\begin{array}{l}2.802 \\
2.771\end{array}$ & $\begin{array}{l}1 \\
5 \\
1 \\
3 \\
5\end{array}$ & $\begin{array}{r}2 \\
17 \\
5 \\
10 \\
15\end{array}$ & & & $\begin{array}{l}2.776 \\
2.770 \\
2.783 \\
2.764 \\
2.763\end{array}$ & $\begin{array}{c}.50 \\
.29\end{array}$ & $\begin{array}{l}173.2 \\
172.9 \\
173.7 \\
172.5 \\
172.4\end{array}$ \\
\hline & 1 & 20 & $\begin{array}{r}2.789 \\
\end{array}$ & $\begin{array}{r}2.779 \\
-\end{array}$ & 2.785 & $\begin{array}{l}1 \\
1 \\
2 \\
1 \\
5\end{array}$ & $\begin{array}{r}15 \\
6 \\
9 \\
2 \\
61\end{array}$ & $\begin{array}{l}2.767 \\
2.771 \\
2.747 \\
2.769\end{array}$ & $\begin{array}{l}2.753 \\
2.741 \\
2.750\end{array}$ & $\begin{array}{l}2.743 \\
2.764 \\
2.764 \\
2.744 \\
2.761\end{array}$ & \begin{tabular}{c}
1.51 \\
\hdashline .84 \\
.84 \\
\end{tabular} & $\begin{array}{l}171.2 \\
172.5 \\
172.5 \\
171.3 \\
172.3\end{array}$ \\
\hline & $\begin{array}{c}6 \\
-5 \\
2\end{array}$ & $\begin{array}{l}22 \\
-22 \\
10 \\
---\end{array}$ & $\begin{array}{l}2.808 \\
2.788 \\
2.812\end{array}$ & \begin{tabular}{r}
2.775 \\
\hdashline 2.765 \\
2.789
\end{tabular} & $\begin{array}{r}2.791 \\
2.780 \\
2.802\end{array}$ & $\begin{array}{l}6 \\
2 \\
5 \\
2 \\
1\end{array}$ & $\begin{array}{r}64 \\
3 \\
48 \\
21 \\
9\end{array}$ & $\begin{array}{l}2.789 \\
2.760 \\
2.754 \\
2.787 \\
2.743\end{array}$ & & $\begin{array}{l}2.756 \\
2.748 \\
2.753 \\
2.740\end{array}$ & $\begin{array}{r}.80 \\
-1.15 \\
1.72 \\
\hdashline--\end{array}$ & $\begin{array}{l}172.8 \\
172.0 \\
171.5 \\
171.8 \\
171.0\end{array}$ \\
\hline & 3 & 11 & 2.799 & 2.772 & $\begin{array}{r}2.785 \\
2.780\end{array}$ & $\begin{array}{l}3 \\
2 \\
1 \\
2\end{array}$ & $\begin{array}{r}34 \\
6 \\
2 \\
9\end{array}$ & & & $\begin{array}{l}2.760 \\
2.771 \\
2.761 \\
2.752\end{array}$ & .94 & $\begin{array}{l}172.2 \\
172.9 \\
172.3 \\
171.8\end{array}$ \\
\hline & 1 & 10 & $\begin{array}{l}2,802 \\
2.908\end{array}$ & $\begin{array}{r}2.789 \\
2.890\end{array}$ & $\begin{array}{r}2.795 \\
2.898\end{array}$ & $\begin{array}{l}1 \\
5 \\
6 \\
1\end{array}$ & $\begin{array}{r}4 \\
17 \\
24 \\
5\end{array}$ & $\begin{array}{l}2.796 \\
2.811 \\
2.874\end{array}$ & $\begin{array}{l}2.777 \\
2.774 \\
2.868\end{array}$ & $\begin{array}{l}2.788 \\
2.798 \\
2.871\end{array}$ & $\begin{array}{c}.14 \\
-.93 \\
.93\end{array}$ & $\begin{array}{l}174.0 \\
174.6 \\
179.2\end{array}$ \\
\hline & $\begin{array}{l}1 \\
1 \\
1 \\
1\end{array}$ & $\begin{array}{l}4 \\
5 \\
3 \\
3\end{array}$ & $\begin{array}{l}2.883 \\
2.854 \\
2,889 \\
2.813\end{array}$ & $\begin{array}{l}\text { 2. } 869 \\
2.839 \\
2.887 \\
2.806\end{array}$ & $\begin{array}{l}2.878 \\
2.848 \\
2.888 \\
2.810\end{array}$ & $\begin{array}{l}1 \\
1 \\
1 \\
1\end{array}$ & $\begin{array}{l}7 \\
3 \\
6 \\
4\end{array}$ & $\begin{array}{l}2.757 \\
2.769 \\
2.903 \\
2.778\end{array}$ & $\begin{array}{l}2.742 \\
2.743 \\
2.878 \\
2.777\end{array}$ & $\begin{array}{l}2,754 \\
2.758 \\
2.888 \\
2.778\end{array}$ & \begin{tabular}{c}
4.31 \\
3.16 \\
\hdashline 1.14
\end{tabular} & $\begin{array}{l}172.1 \\
180.2 \\
173.4\end{array}$ \\
\hline & 1 & 3 & 2. 832 & 2. 821 & 2. 827 & $\begin{array}{l}1 \\
1 \\
1 \\
1\end{array}$ & $\begin{array}{l}6 \\
4 \\
3 \\
3\end{array}$ & $\begin{array}{l}2.814 \\
2.694 \\
2.745 \\
2.727\end{array}$ & $\begin{array}{l}2.809 \\
2.689 \\
2.744 \\
2.718\end{array}$ & $\begin{array}{l}2.692 \\
2.744 \\
2.723\end{array}$ & \begin{tabular}{c}
.57 \\
\hdashline .5 \\
.-- \\
.-
\end{tabular} & $\begin{array}{l}168.2 \\
171.2 \\
170.2\end{array}$ \\
\hline
\end{tabular}

1 Identification of serial numbers given in Table 1. 
Porosity values are of interest in studying the weathering qualities of a material, but, in general, the determination is too difficult and tedious for specification purposes. A sufficiently accurate indication of porosity for comparative purposes is obtained by the absorption test. Evidently the porosity value for any material should be equal to or greater than the volume absorption value. In the specificgravity determinations the true value was determined on one speciment of the sample and the apparent on another. The porosity values are so small that a slight error in either determination or a slight variation of the material will lead to erroneous porosity results.

Most of the porosity values found were between 0.3 and 1 per cent, although one value was 0.14 per cent and another over 4 per cent. The latter was obtained on a sample taken from the surface of the ground and hence is not representative of material below the weathered zone.

\section{SPECIFIC GRAVITY}

The "true specific gravity" of a porous material may be considered as the ratio of the weight of a certain volume of material to the weight of the same volume of water at the same temperature, assuming that the material has been compressed until the pores are entirely filled. It is not feasible to eliminate the pores by compression, but the material can be pulverized until the component particles are separated. Determinations given in Table 7 were made on material pulverized and passed through a 100-mesh sieve. Various types of specific-gravity apparatus were tried, but the most concordant results were obtained with the LeChatelier flask. As this apparatus requires a much larger sample than other types and the process is less tedious, it was employed for the tests. By using considerable care in removing the air from the powders and correcting for temperature differences between the initial and final volume readings it was found possible to obtain quite consistent results. A 95 per cent ethyl alcohol was used as the liquid, since there was no difficulty in immersing all of the powdered material in it, while other liquids had a tendency to float some of the fine powder.

The apparent specific gravity of a porous material is the ratio of weight of a certain volume of the material in its natural state to the weight of the same volume of water at the same temperature. The results given in Table 7 were determined from dry weights of regularshaped specimens and the corresponding volumes obtained by weighing the saturated specimens immersed in water. The reduction formula was

$$
A=\frac{w_{1} d}{w_{2}-w_{3}}
$$

where $w_{1}=$ dry weight of specimen, $d=$ apparent density of the water at the temperature of observation, $w_{2}=$ weight of the specimen after immersion in water for 48 hours, and $w_{3}=$ weight of saturated specimen suspended in water. It is necessary to use soaked specimens for determining the weight suspended in water to prevent errors due to absorption during the operation.

\section{WEIGHTS PER CUBIC FOOT}

Having determined the apparent specific gravity or "bulk density" of a material, it is only necessary to multiply this value by the weight of a cubic foot of water in order to deduce the weight per cubic foot 
of the sample. The results in the last column of Table 7 were obtained by multiplying the average apparent specific-gravity value for each sample by 62.35 . The average and extreme weights per cubic foot for slate from various districts were as follows:

Weight per cubic foot

\begin{tabular}{|c|c|c|c|c|}
\hline District & $\begin{array}{l}\text { Number } \\
\text { of tests }\end{array}$ & A verage & Maximum & Minimum \\
\hline $\begin{array}{l}\text { Maine } \\
\text { Vermont-New York } \\
\text { Hard Vein, Pa. } \\
\text { Bangor, } \mathrm{Pa}\end{array}$ & $\begin{array}{r}21 \\
93 \\
16 \\
108\end{array}$ & $\begin{array}{r}\text { Pounds } \\
175.3 \\
173.7 \\
172.7 \\
172.6\end{array}$ & $\begin{array}{l}\text { Pounds } \\
176.1 \\
175.5 \\
173.2 \\
174.8\end{array}$ & $\begin{array}{r}\text { Pounds } \\
174.3 \\
172.1 \\
171.9 \\
171.5\end{array}$ \\
\hline $\begin{array}{l}\text { Pen Argyl, } \mathrm{Pa} \\
\text { Wind Gap, Pa } \\
\text { Slatington, Pa } \\
\text { Virginia }\end{array}$ & $\begin{array}{r}185 \\
78 \\
51 \\
52\end{array}$ & $\begin{array}{l}172.4 \\
171.5 \\
172.2 \\
174.8\end{array}$ & $\begin{array}{l}174.0 \\
173.9 \\
173.0 \\
179.3\end{array}$ & $\begin{array}{l}170.9 \\
170.7 \\
171.8 \\
173.1\end{array}$ \\
\hline
\end{tabular}

The above values, considered in conjunction with service records of the slates, afford considerable evidence that a correlation exists between bulk density and durability. However, as will be shown later, the durability of slate is influenced to such a large extent by the presence of small amounts of certain minerals, it would not be logical to base judgment upon this determination alone.

\section{WEATHERING CHARACTERISTICS}

\section{WEATHERING PROCESSES}

In the study of slate weathering, about 60 samples of old shingles were collected which had been exposed to the elements for various periods of time up to 131 years. Where an appreciable amount of decay was in evidence the decayed portion was subjected to a partial chemical analysis to determine if any alteration in composition of the less stable minerals had occurred. Specimens were also subjected to strength, toughness, and absorption tests to determine the physical alterations. A summary of these results is shown in Table No. 8.

TABLE 8.-Summary of tests on weathered slate

\begin{tabular}{|c|c|c|c|c|c|c|c|c|c|c|c|}
\hline \multirow{2}{*}{ Producing region } & \multirow{2}{*}{$\begin{array}{c}\text { Num- } \\
\text { ber } \\
\text { of } \\
\text { sam- } \\
\text { ples } \\
\text { exam- } \\
\text { ined }\end{array}$} & \multirow{2}{*}{$\begin{array}{l}\text { Aver- } \\
\text { age } \\
\text { wea- } \\
\text { ther- } \\
\text { ing } \\
\text { period }\end{array}$} & \multicolumn{2}{|c|}{$\begin{array}{l}\text { Average modu- } \\
\text { lus of rupture }\end{array}$} & \multicolumn{2}{|c|}{$\begin{array}{l}\text { Average } \\
\text { toughness } \\
\text { values }\end{array}$} & \multicolumn{2}{|c|}{$\begin{array}{l}\text { A verage } \\
\text { absorption } \\
\text { by weight }\end{array}$} & \multicolumn{3}{|c|}{$\begin{array}{l}\text { Indicated change per year } \\
\text { due to weathering }\end{array}$} \\
\hline & & & $\begin{array}{l}\text { Fresh } \\
\text { slate }\end{array}$ & $\begin{array}{l}\text { Wea- } \\
\text { ther- } \\
\text { ed } \\
\text { slate }\end{array}$ & $\begin{array}{l}\text { Fresh } \\
\text { slate }\end{array}$ & \begin{tabular}{|} 
Wea- \\
ther- \\
ed \\
slate
\end{tabular} & $\begin{array}{l}\text { Fresh } \\
\text { slate }\end{array}$ & $\begin{array}{l}\text { Wea- } \\
\text { ther- } \\
\text { ed } \\
\text { slate }\end{array}$ & $\begin{array}{l}\text { Modu- } \\
\text { lus of } \\
\text { rupture }\end{array}$ & $\begin{array}{c}\text { Tough- } \\
\text { ness }\end{array}$ & $\begin{array}{c}\text { Absorp- } \\
\text { tion }\end{array}$ \\
\hline $\begin{array}{l}\text { Maine } \\
\text { Vermont-New York.- } \\
\text { Hard Vein, } \mathrm{Pa} \text {. } \\
\text { Soft Vein, } \mathrm{Pa} \mathrm{l}_{-} \\
\text {Virginia.. }\end{array}$ & $\begin{array}{r}4 \\
3 \\
12 \\
29 \\
9\end{array}$ & $\begin{array}{r}\text { Years } \\
46 \\
40 \\
54 \\
24 \\
81\end{array}$ & $\begin{array}{c}\text { Lbs./in. }{ }^{2} \\
11,700 \\
10,600 \\
13,600 \\
11,700 \\
10,500\end{array}$ & \begin{tabular}{|c|} 
Lbs.l \\
in.2 \\
10,100 \\
8,700 \\
9,000 \\
9,600 \\
9,600
\end{tabular} & \begin{tabular}{|} 
Inch \\
0.178 \\
.163 \\
.204 \\
.201 \\
.164
\end{tabular} & $\begin{array}{r}\text { Inch } \\
0.168 \\
.160 \\
.168 \\
.189 \\
.144\end{array}$ & $\begin{array}{l}\text { Per } \\
\text { cent } \\
0.05 \\
.13 \\
.16 \\
.31 \\
.06\end{array}$ & $\begin{array}{l}\text { Per } \\
\text { cent } \\
0.06 \\
.23 \\
.85 \\
.68 \\
.15\end{array}$ & $\begin{array}{c}\text { Los./in. }{ }^{2} \\
-35 \\
-47 \\
-85 \\
-100 \\
-11\end{array}$ & $\begin{array}{c}\text { Inch } \\
-0.0002 \\
-.0007 \\
-.0006 \\
-.0005 \\
-.0002\end{array}$ & $\begin{array}{r}\text { Per cent } \\
+0.0002 \\
+0025 \\
+0128 \\
+0154 \\
+0011\end{array}$ \\
\hline
\end{tabular}

1 Slates from Bangor and Pen Argyl region.

A large range in the resistance of the various slates was evident from the examination of weathered samples. The chemical analysis revealed, in most cases, a considerable amount of gypsum in the weathered portion, while the fresh slates showed almost none. It 
seemed probable, therefore, that some of the calcite in the slate was converted to gypsum in the weathering process. Two means were considered possible for this change-first, the action of sulphur acids from the air on the calcite, and, second, an interaction between the sulphide minerals and calcite. Sulphides of iron are usually present in slate.

If gypsum could be formed from an interaction of the constituent minerals of slate, it was assumed that the weathering process could be simulated in the laboratory by merely soaking and drying the material several times. The following experiments were made for that purpose: Three samples of slate were selected which were known to have poor weathering qualities. Determinations of $\mathrm{SO}_{3}$ were made on each in the original condition and after the samples had been subjected to 30 cycles of soaking and drying. The following results were obtained:

Sample No. 1:

$\mathrm{SO}_{3}$

(a) In original condition 0.01

(b) After 30 cycles of soaking and drying

Sample No. 2:

(a) In original condition

Sample No. 3 :

(a) In original condition

(b) After 30 cycles of soaking and drying

A portion of each of these three samples, after the soaking and drying process, was powdered and leached with distilled water. The leach was then filtered and evaporated. An abundance of crystals was obtained which was examined with the petrographic microscope and proven to be gypsum. In these experiments it was considered that the sulphur acids of the air could play no appreciable part and that the gypsum was due practically entirely to the reaction between the calcite and sulphide minerals, the oxygen necessary for completing the $\mathrm{SO}_{3}$ radicle being drawn from the air.

It was desirable to study the reaction between iron sulphide and calcite alone as well as in the presence of carbon. For this purpose four mixtures were made, as follows: (1) Equal parts of calcite and pyrite; (2) equal parts of calcite and marcasite; (3) same as (1) with a small addition of carbon; (4) same as (2), with a small addition of carbon. The four mixtures were placed in open beakers, covered with distilled water, and allowed to stand for seven hours at room temperatures. The beakers were then set in a drying oven at $110^{\circ} \mathrm{C}$. for 17 hours. The 7 hours' soaking and 17 hours' drying constituted a cycle which was repeated one hundred times. The water-soluble matter was then extracted and determined as follows:

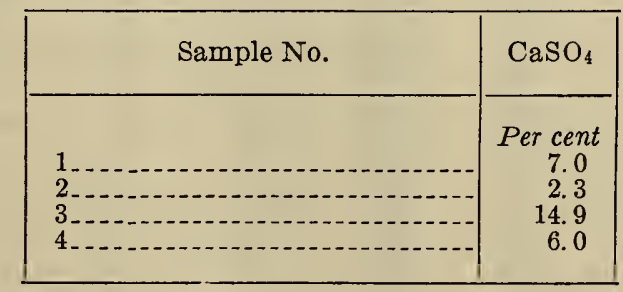

These experiments indicate that a chemical reaction between pyrite and calcite or between marcasite and calcite occurs under such conditions and results in the formation of gypsum. They also indicated that the presence of carbon accelerates the rate of reaction. 
Since this chemical change has been found to occur in slates containing appreciable amounts of calcite and iron sulphides, it remains to be considered how this may produce decay. The gypsum molecule requires about twice as much space as the calcite molecule, hence the conversion to gypsum of a calcite crystal, which is embedded in another material, must produce stresses in the surrounding material. Slates containing considerable amounts of both pyrite and calcite, when subjected to several cycles of soaking and drying, disintegrated almost completely. Slates of the same kind in actual exposure on the roof of a building are found to decay more rapidly on the unexposed parts. This seems to indicate that in service the solubility of gypsum comes into consideration. As the rain water leaches downward through the slate some of the gypsum is carried in solution and deposited at a lower level. By this process the gypsum is concentrated on the lower sides of shingles and the recrystallization within the pores causes internal stresses. The analyses made on weathered shingles showed, in most cases, a concentration of gypsum in the decayed parts.

Soaking and drying tests have been made on numerous samples of slates which were known to have poor weathering qualities by drying at $110^{\circ} \mathrm{C}$. for 17 hours and soaking 7 hours. Under such conditions some of the samples showed signs of decay in 30 cycles and an advanced state of disintegration in less than 50 cycles. Some producers contended that the drying temperatures were too high in these tests and out of proportion to those of service conditions. For this reason a series of tests was made in which the drying temperature was $50^{\circ} \mathrm{C}$. This temperature was assumed to be about equivalent to roof temperatures on hot summer days. The results are given in Table 9, and show that the deterioration occurs under such conditions but at a much slower rate.

TABLE 9.-Soaking and drying tests with absorption and weight determinations after 200 cycles $^{1}$

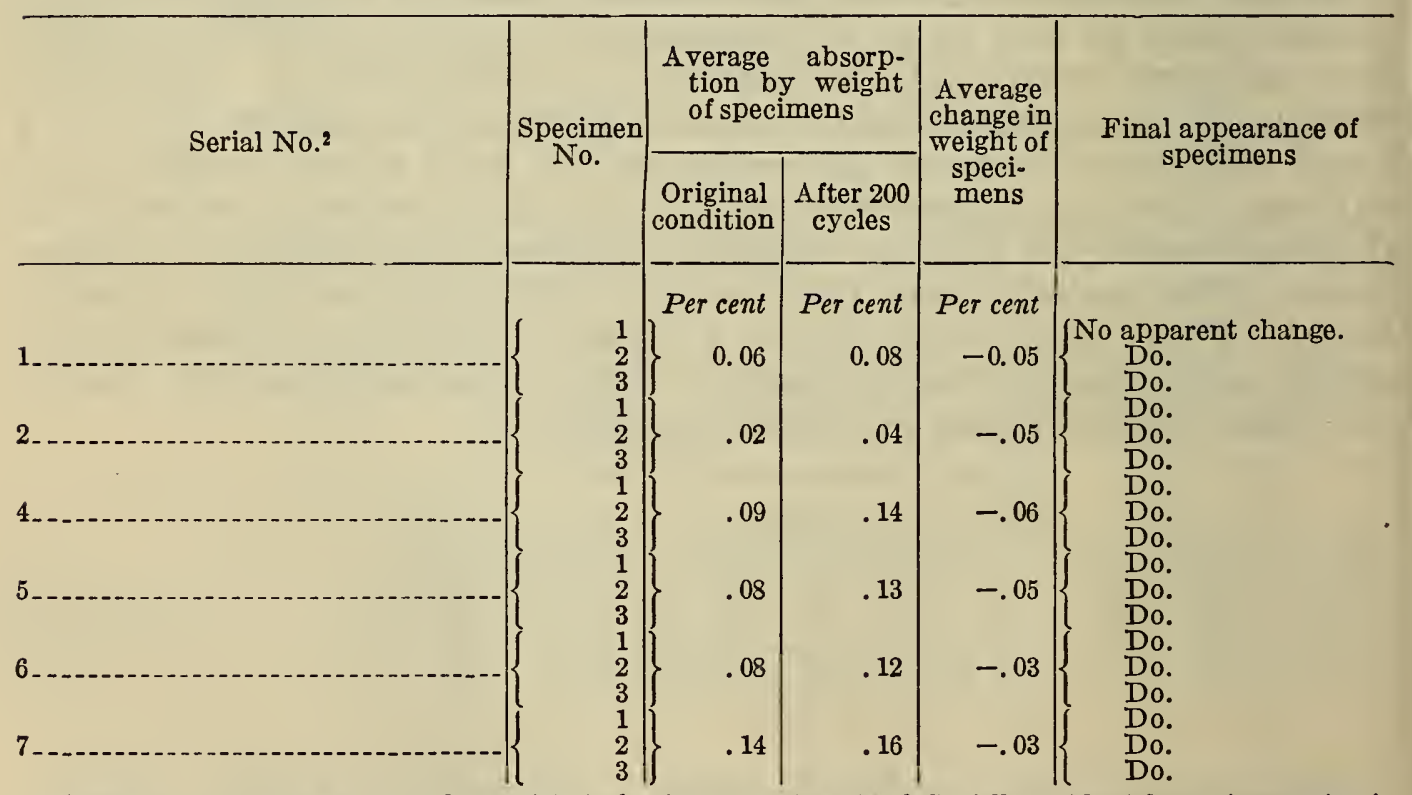

1 In the first 100 cycles each cycle consisted of 17 hours drying at $50^{\circ} \mathrm{C}$., followed by 7 hours immersion in water at room temperatures. In the second 100 cycles each cycle consisted of 24 hours drying at $50^{\circ} \mathrm{C}$. and 24 hours immersion in water at room temperatures.

2 For identification of serial numbers see Table 1. 
TABLE 9.-Soaking and drying tests with absorption and weight determinations after 200 cycles-Continued

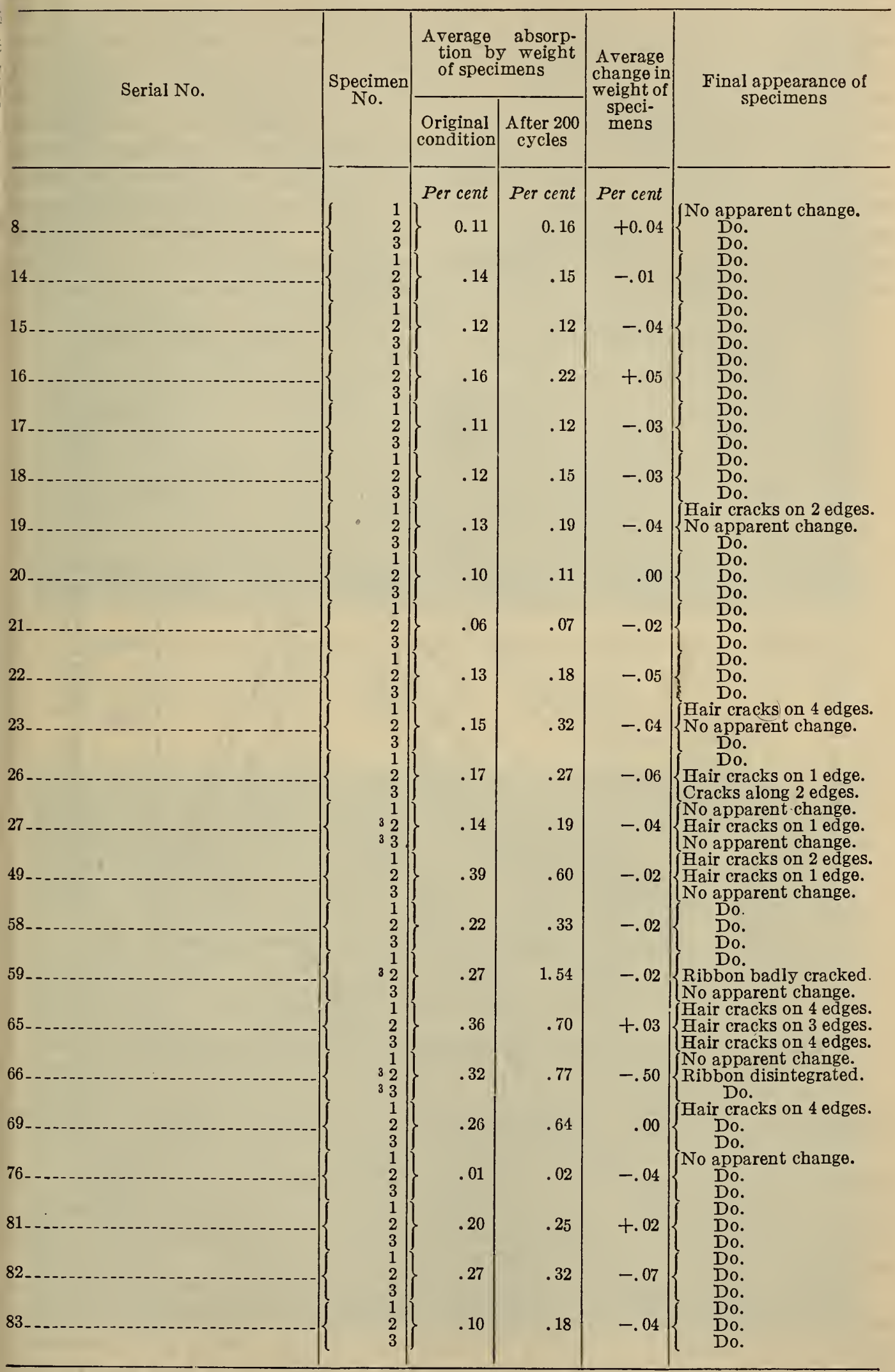

${ }^{3}$ Specimens contained a dark ribbon. Those not so marked are clear slate. 
In order to determine if a relation exists between the results obtained in the soaking and drying tests and the resu ts of actual weathering it is necessary to have some definite measure of the deterioration. It is fair to assume that a decrease in strength or an increase in absorption is indicative of deterioration. In Table 9 is shown the computed rate of "strength loss" and "absorption increase" per year for weathered slate from five producing districts. These rates are based on the average strength and absorption results obtained on the fresh material as compared to the results obtained on slate shingles after exposure to the weather. It was found that these yearly rates of change were approximately one-twentieth part of the corresponding changes obtained in 200 cycles of the soaking and drying test when the specimens were dried at $50^{\circ} \mathrm{C}$. Figure 4 shows the "absorption increases"

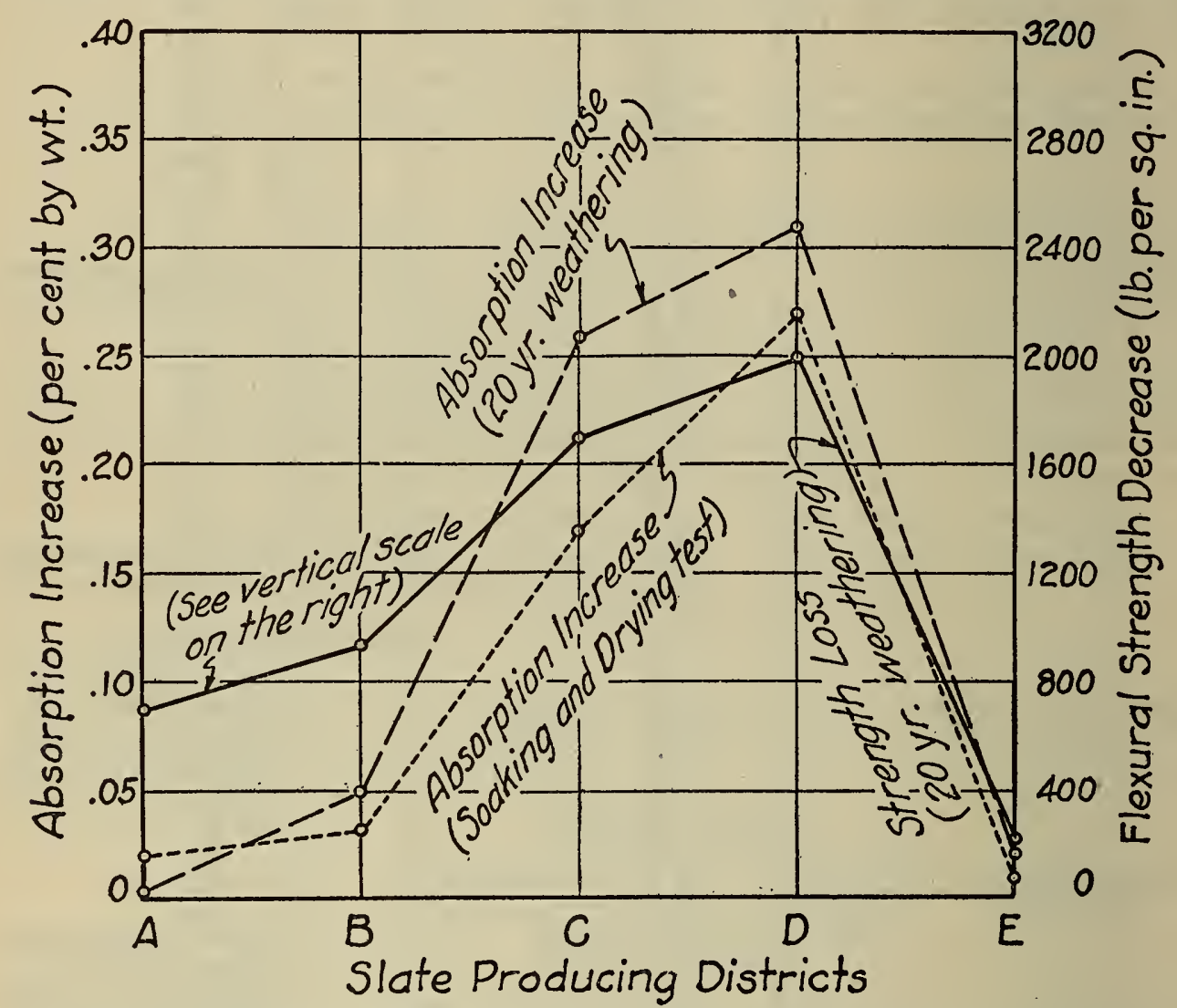

FigTRE 4.-Relation between strength loss for 20 years weathering, absorption increase for 20 years weathering and absorption increase in the soaking and drying test

Plotted points are the respective averages of all specimens from five districts as follows: $A$, Maine; $B$, Vermont-New York; $C$, Hard Vein, Pa.: $D$, Soft Vein, Pa., $E$, Virginia.

obtained in the soaking and drying tests plotted with the computed "absorption increases" and "strength losses" for 20 years weathering. These curves indicate that the soaking and drying test gives results similar to those of actual weathering.

Thermal expansion and contraction of the component minerals has often been mentioned as a possible cause of deterioration. This was studied by means of a series of tests on samples from five districts. The samples were heated in an oven for 17 hours and laid out in the laboratory for 7 hours. Two of the samples were disintegrated by 63 cycles but the others were continued in the test to 554 cycles. 


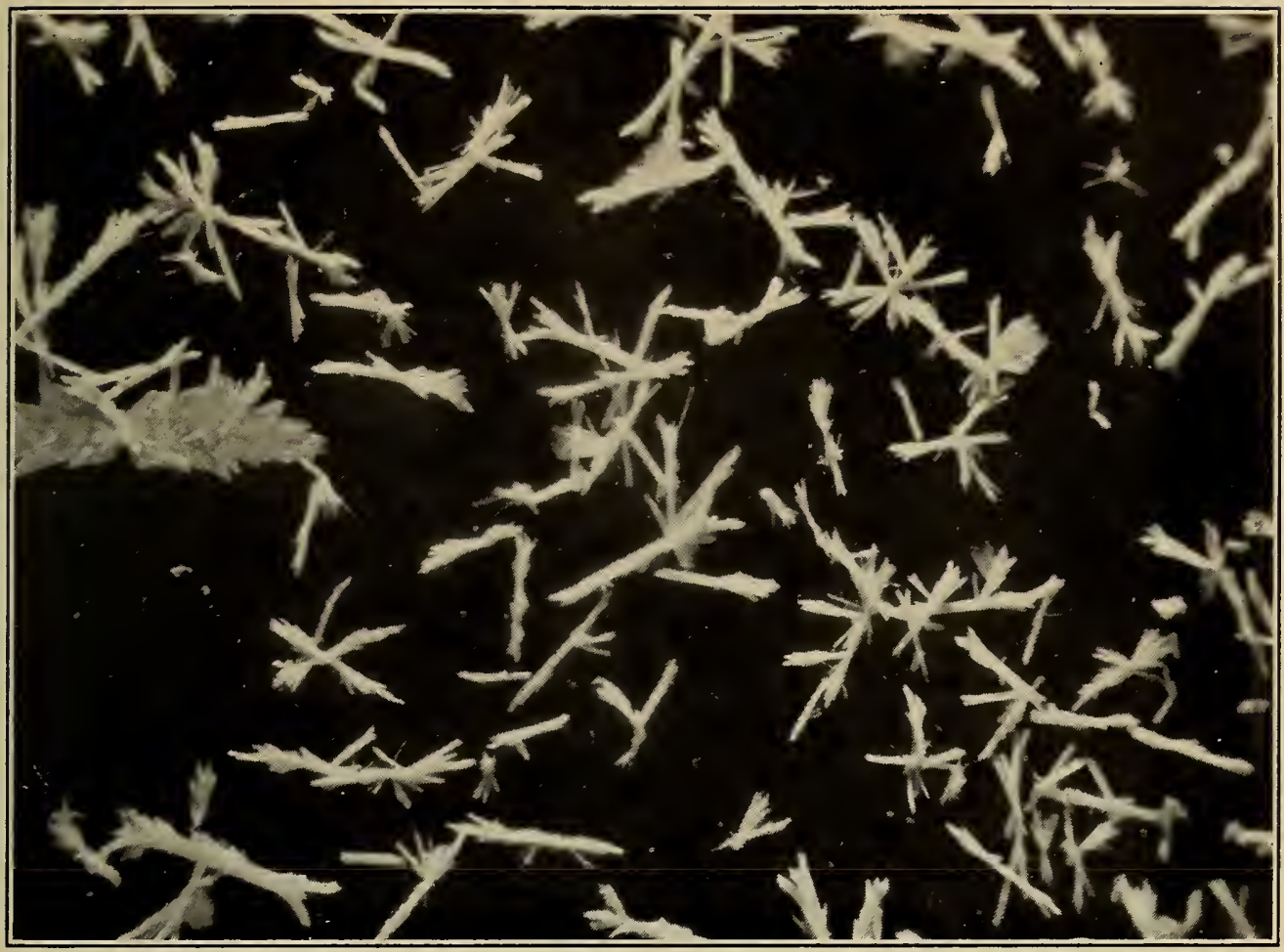

FIGURE 5.-Photomicrograph of calcium sulphate crystals obtained by evaporating the leach from a sample of Pen Argyl (Pa.) slate which had been heated and cooled 310 cycles

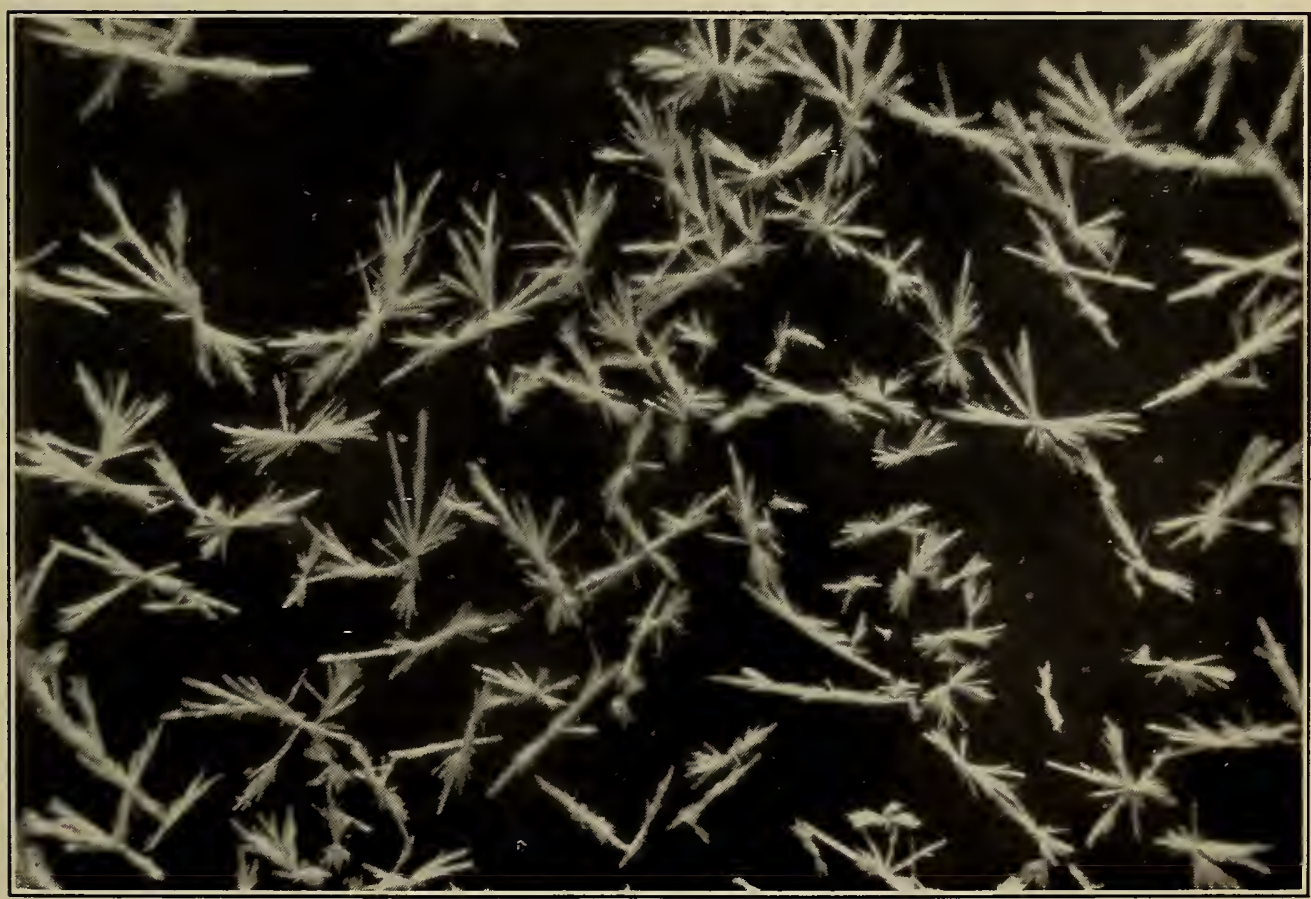

FIGURE 6.-Photomicrograph of calcium sulphate crystals obtained by evaporating the leach from a sample of Bangor ( $P$ a.) ribbon slate that had been heated and cooled 63 cycles 
The results were judged by means of inspection and by absorption tests after 25, 50, and 554 cycles. The detailed results are given in Table 10. The s'ates which had previously shown a high resistance to the soaking and drying test showed little deterioration in the heating and cooling procedure. As those samples which decayed in this test presented about the same appearance as samples which decayed in the soaking and drying test, they were examined for gypsum and it was found in considerable amounts. Figures 5 and 6 are photomicrographs of the crystals obtained by leaching serial Nos. 58 and 27, respectively. Hence, it is probable that decay was caused mainly by the formation of gypsum. Most of the samples showed considerable resistance to the heating and cooling process, especially those of low calcite content, which seems to indicate that the effect of temperature changes on slate is slight unless it results in such chemical alterations as described above. The tests also indicate that considerable amounts of moisture are not necessary to bring about the reaction. Furthermore, they supply a c.ue to the cause of decay sometimes noted on interior slate installations.

TABLE 10.-Effect of repeated heating and cooling on slates from five different regions

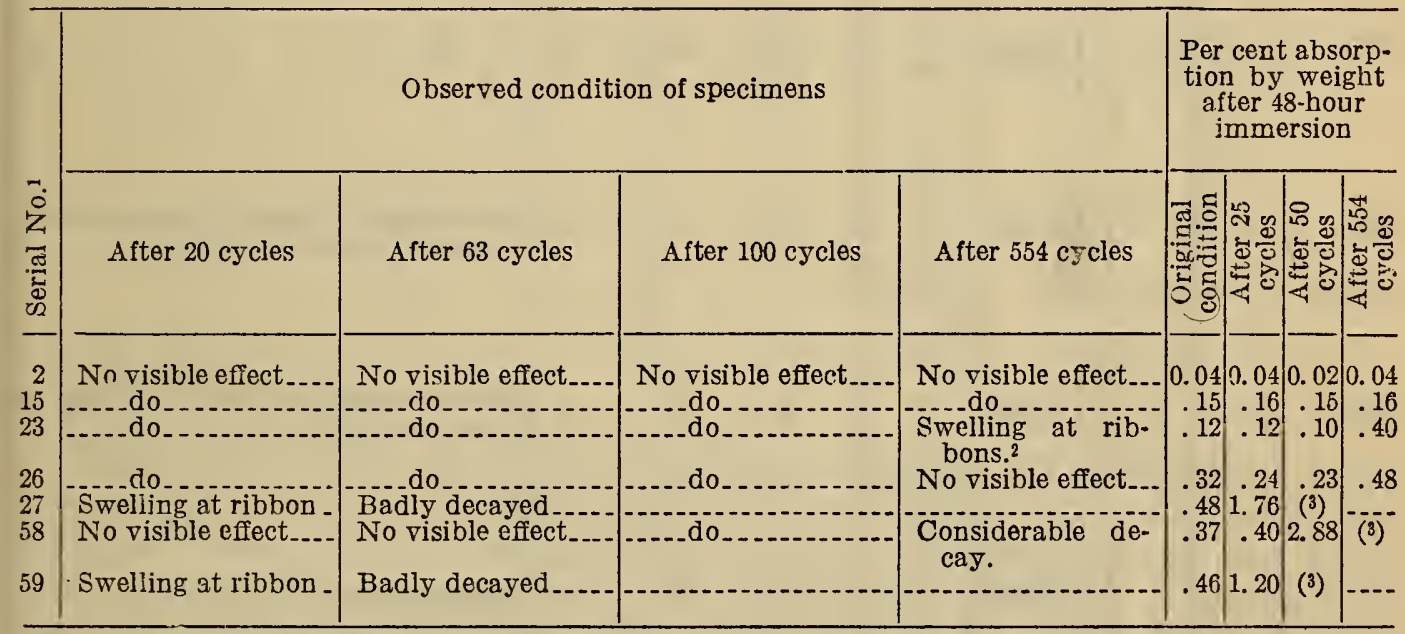

1 Identification of serial numbers given in Table 1.

2 On 1 specimen the ribbons were crumbling at the surface.

Specimens were too badly decayed for absorption determination. 1 specimen of No. 58 was in an advanced state of decay at 310 cycles.

Frost action is considered to be one of the common causes of stone weathering. Table 11 gives the results of freezing tests on 18 samples from the various districts. The samples were slabs 4 inches square and approximately one-half inch thick. They were soaked 14 days before freezing was started and then thawed each time by immersion in water at about $20^{\circ} \mathrm{C}$. for 30 minutes. The temperature of the freezing chamber was maintained at approximately $-10^{\circ} \mathrm{C}$. and two freezings were made each day. In these tests only one sample failed and this occurred after 1,374 cycles. This sample was originally taken from the surface of the ground and showed signs of weathering when received. Five of the samples were continued in the test until 2,436 cycles were reached and the others were discontinued after 1,743 cycles. The results were judged by inspection and by absorption tests. 
TABLE 11.-Results of freezing tests

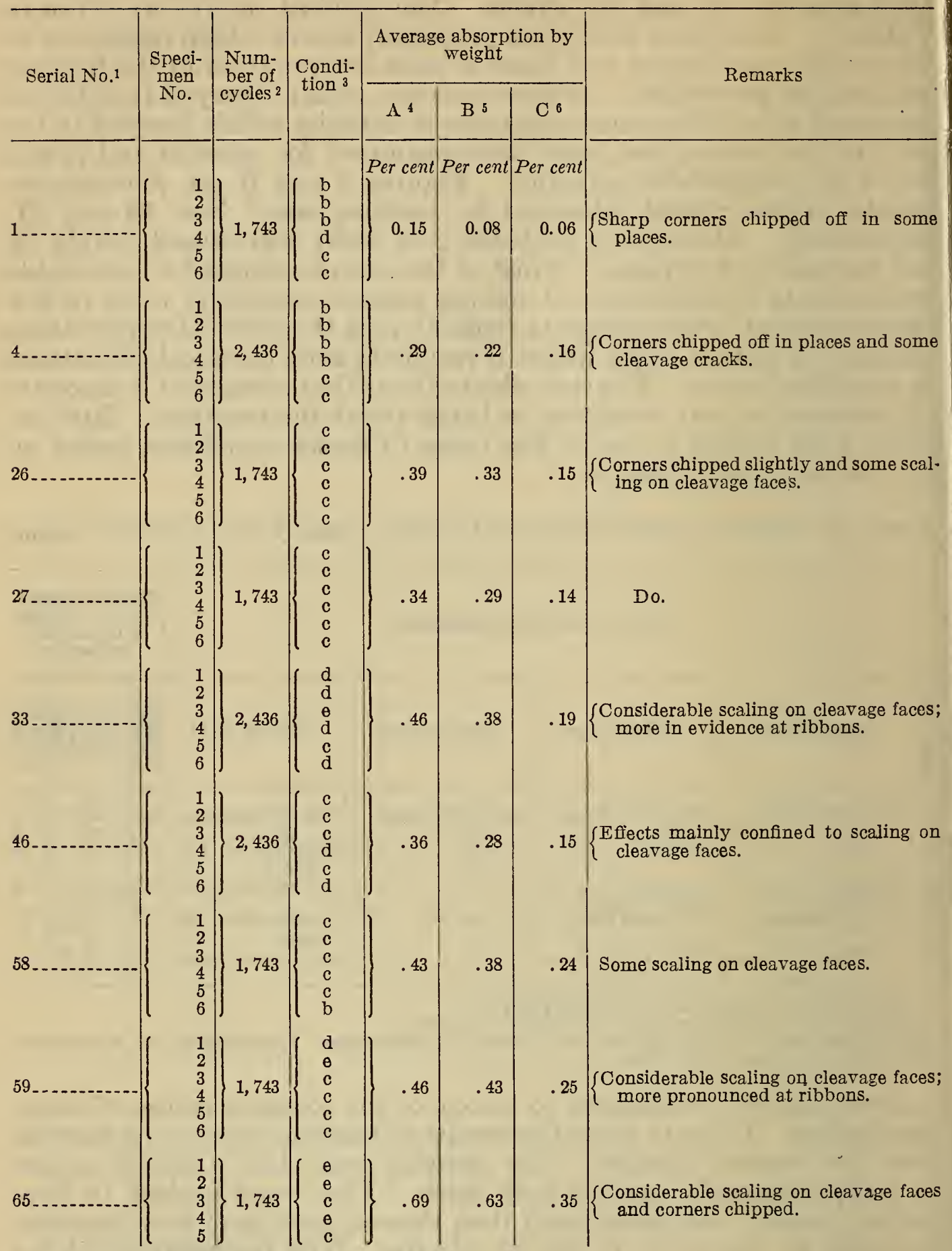

1 Identification of serial numbers given in Table 1.

2 A cycle consisted of 1 freezing and 1 thawing as outlined on p. 405.

8 The final state of the specimens was estimated by inspection and expressed in 8 stages as follows: "a" signifies no decay, " $h$ " advanced state of decay. The intervening letters represent about equal stages of decay between "a" and " $h$ ""

4 Percentage of water absorbed during the freezing and thawing process.

3 Absorption obtained by drying the specimens after the freezing procedure and then immersing them for 48 hours.

6 Absorption of samples in ariginal condition. 
TABLE 11.-Results of freezing tests-Continued

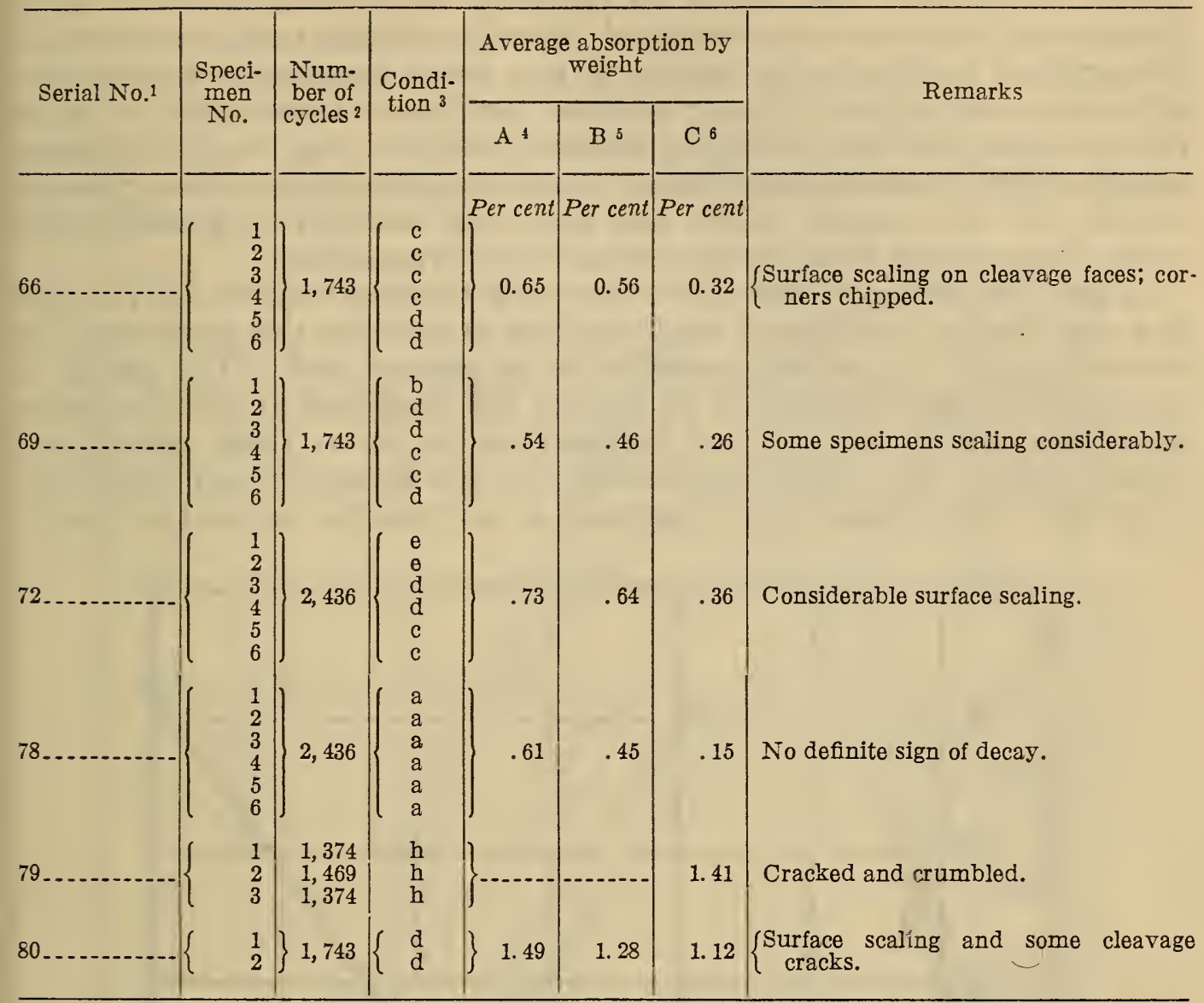

See footnotes on p. 406 .

While all of the samples showed an increase in absorption after repeated freezing and thawing, and while surface scaling was observed in most cases, it can not be said that any sample (except one mentioned above) had reached an advanced state of decay. In view of the large number of cycles of freezing it may be concluded that the action of frost on slate is not a very serious cause of decay. This is especially true of those slates which are subject to the chemical changes discussed above, since that action is several times as severe. However, it should be considered that when decay has started from any cause then frost action can proceed at a more rapid rate.

\section{WEATHERING TEST PROCEDURE}

The soaking and drying test requires a month or more to carry the weathering process to a definite visible stage. A more rapid acceptance test is often desirable. Several procedures, such as the change in strength or absorption, have been used to measure the effects of the weathering test at some intermediate stage of the process. The strength criterion has not proven very satisfactory, because one can not determine the original strength of the actual specimens used in the weathering test. Determinations on separate specimens of the sample may prove very misleading, due to the natural variation of the material. Figure 7 shows the average strength losses for a large number of specimens after 10,20, and 30 cycles of soaking and drying. In this series of tests the specimens were dried 
17 hours at $110^{\circ} \mathrm{C}$. and soaked 7 hours at about $20^{\circ}$. This shows that the strength loss up to 20 cycles is slight and unless a large number of specimens are averaged the effect might not be discerned. Absorption tests can be made on the same specimens before and after the soaking and drying process, and such tests afford a more reliable criterion than strength determinations. An indirect means which offers considerable promise consists in determining the gypsum content of the sample before and after the weathering process, and using the gypsum increase as a measure of weathering.

A test procedure which has been used to some extent for judging the weathering qualities of slate consists of soaking the specimens for seven days in a 1 per cent solution of sulphuric acid. The depth of softening is then determined by gaging the thickness of the specimens at several points, scraping off the softened layer at these points and gaging again. By using a dull blade for the scraping and standardizing the conditions of the process it is possible to obtain fairly

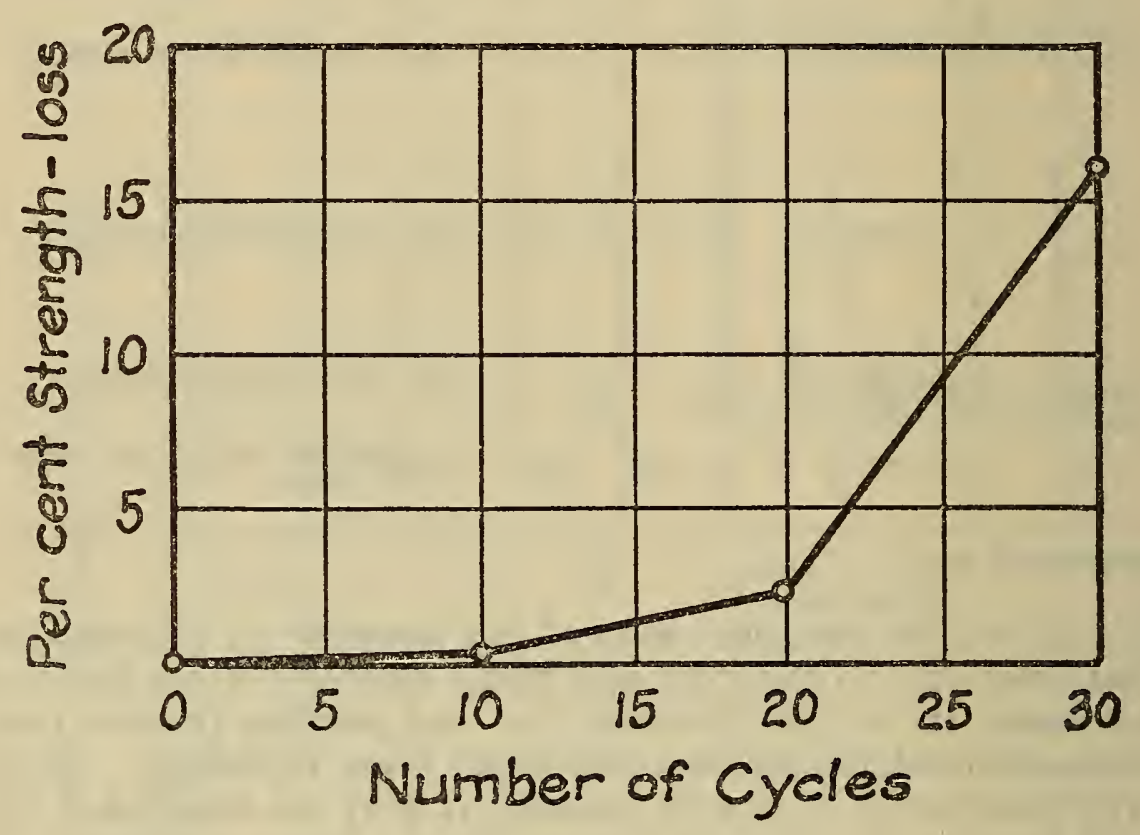

FIGURE 7.-Average strength-loss for 16 samples of slate from 1 district after 10, 20, and 30 cycles of soaking and drying

consistent results. This test converts the calcite near the surface to gypsum and causes decay similar to that obtained in the soaking and drying test. Slates which have a low calcite content are not appreciably affected by this test. The absorption of the slate may have a marked effect. Evidently this test would lead to erroneous conclusions if applied to slates containing considerable calcite, but very little sulphide of iron. All of the slates now being produced in this. country contain considerable amounts of pyrite so the acid test is applicable to our present commercial materials.

Table 12 gives the results of such tests on several samples representing the various producing districts. Figure 8 shows the relations obtained by plotting the average acid resistances of slates from the various districts with absorption increases due to actual weathering as well as absorption increases noted in the soaking and drying test. This test indicates no appreciable difference between the durability of slates from districts $A, B$, and $E$, all of which are generally accepted 
TABLE 12.-Sulphuric acid tests with depth of softening measurements after seven days in 1 per cent $\mathrm{H}_{2} \mathrm{SO}_{4}$-Continued

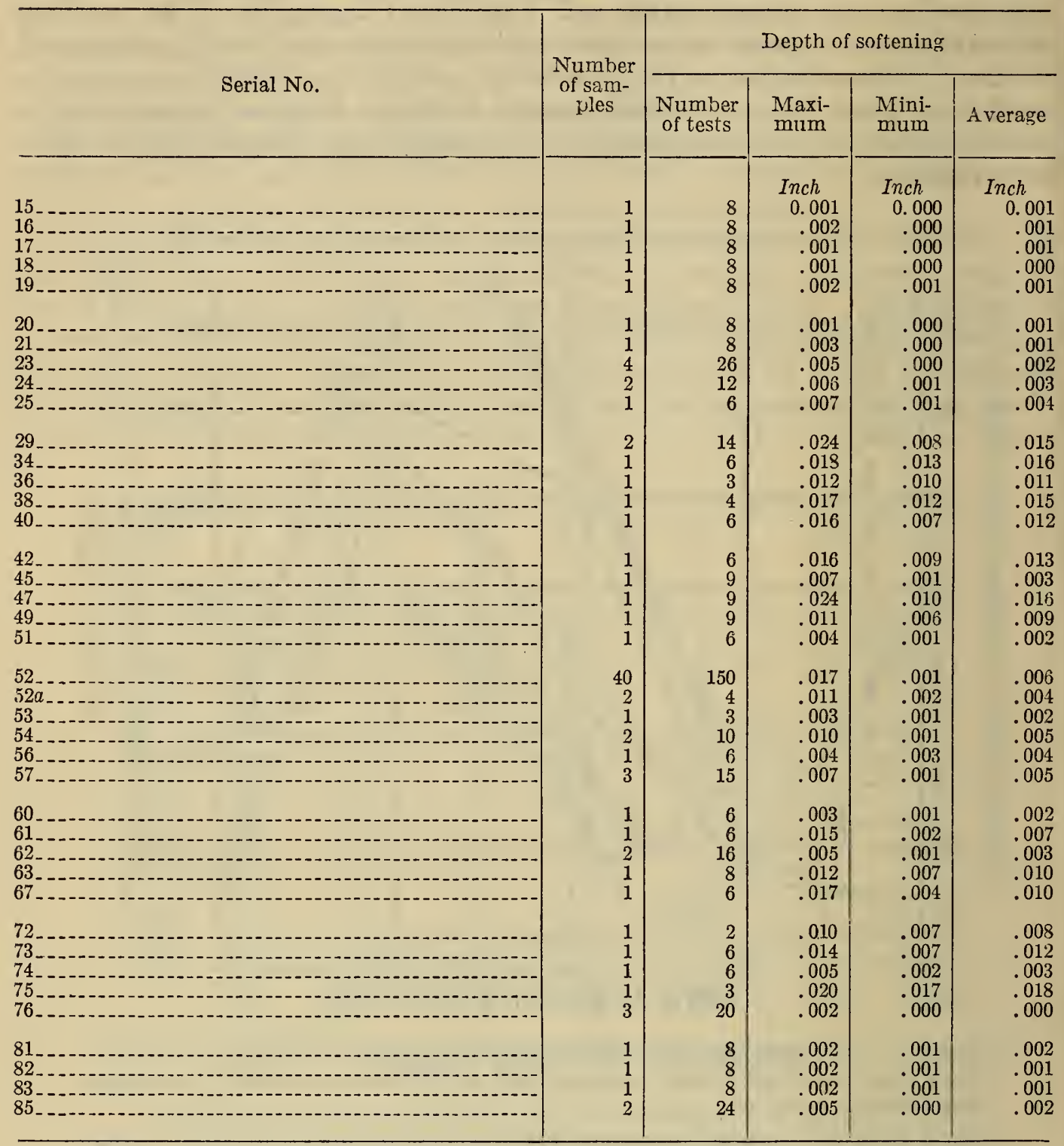

\section{CONCLUSIONS}

1. The flexural strength of slate is much higher than other types of rock used for structural purposes. Although most slates are stronger across the grain than along the grain, this ratio varies greatly with different deposits. The effect of moisture in decreasing the strength is more marked than for other common types of rock.

2. The elastic modulus of slate is high in comparison with other types of rocks. The high flexural strength of the material enables it to be used in relatively thin slabs which have considerable flexibility.

3. Although the porosity determinations in some cases were of rather uncertain precision, they seem to indicate that the void spaces in slate are usually less than 2 per cent of the volume.

4. The bulk density (apparent specific gravity) of slate varies between the limits 2.74 and 2.89 , the average being 2.78 . 
5. The abrasive hardness of slate is about equal to that of the harder oolitic limestones in present-day use in this country.

6 . Slate is probably affected to some extent by frost and atmospheric acids, but the major weathering action is due to, first, chemical interaction between certain mineral constituents and second, internal stresses resulting from the newly-formed compounds.

7. The weather resistance is decreased by appreciable amounts of calcite and pyrite existing together. The presence of free carbon with these two minerals lessens weather resistance.

8. Tests on several samples of weathered slate shingles indicate that the early stages of decay are accompanied by an increase in absorption and decrease in strength. These facts may be found of value in deciding upon the use of shingles which have been exposed to the weather for a few years at the plant or the reuse of shingles removed from a building.

9. The most reliable weathering test for slate appears to be the soaking and drying test. For the slates now being produced in this country the sulphuric acid test gives a sufficiently accurate indication of weathering qualities for specification purposes. For slates containing a considerable amount of calcite but no pyrite the sulphuric acid test would probably lead to erroneous conclusions.

10. The possibility of jnjury to slate due to diurnal temperature changes alone is remote. The chemical transformations occurring in slates, containing considerable amounts of calcite and pyrite, proceed even in dry weather, but at a much slower rate than when more moisture is present. This fact probably accounts for the decay sometimes noted in cases of interior slate construction.

11. Color changes in slate are of two kinds: First, those due to concealment of the true color by an efflorescence giving the effect of fading, and, second, oxidation of ferrous minerals resulting in a more permanent color.

12. The so-called fading of dark-colored slate is confined mainly to those varieties containing considerable amounts of calcite and pyrite. This phenomenon accompanies the weathering process and is believed to be a result of the same chemical changes which produce decay. Color changes due to the oxidation of ferrous minerals are confined mainly to certain varieties of green slate and results in a change from green to brown. Occasionally dark-colored slates take on a brown color after exposure to the weather. This appears to be due to a decomposition of the pyrite and oxidation of the iron compounds.

Washington, June 21, 1932. 